University of Nebraska - Lincoln

DigitalCommons@University of Nebraska - Lincoln

\title{
Factors influencing ground-water recharge in the eastern United States
}

Bernard T. Nolan

U.S. Geological Survey

Richard W. Healy

U.S. Geological Survey, rwhealy@usgs.gov

Patrick E. Taber

U.S. Geological Survey

Kimberlie Perkins

U.S. Geological Survey

Kerie J. Hitt

U.S. Geological Survey

See next page for additional authors

Follow this and additional works at: https://digitalcommons.unl.edu/usgsstaffpub

Part of the Earth Sciences Commons

Nolan, Bernard T.; Healy, Richard W.; Taber, Patrick E.; Perkins, Kimberlie; Hitt, Kerie J.; and Wolock, David M., "Factors influencing ground-water recharge in the eastern United States" (2007). USGS Staff -Published Research. 437.

https://digitalcommons.unl.edu/usgsstaffpub/437

This Article is brought to you for free and open access by the US Geological Survey at DigitalCommons@University of Nebraska - Lincoln. It has been accepted for inclusion in USGS Staff -- Published Research by an authorized administrator of DigitalCommons@University of Nebraska - Lincoln. 


\section{Authors}

Bernard T. Nolan, Richard W. Healy, Patrick E. Taber, Kimberlie Perkins, Kerie J. Hitt, and David M. Wolock 


\section{Factors influencing ground-water recharge in the eastern United States}

\section{Bernard T. Nolan, Richard W. Healy *, Patrick E. Taber, Kimberlie Perkins, Kerie J. Hitt, David M. Wolock}

US Geological Survey, 413 National Center, Reston, VA 20192, United States

Received 11 April 2006; received in revised form 26 June 2006; accepted 28 June 2006

\author{
KEYWORDS \\ Ground water; \\ Recharge; \\ Darcian; \\ Chloride tracer; \\ Nonlinear regression
}

Summary Ground-water recharge estimates for selected locations in the eastern half of the United States were obtained by Darcian and chloride-tracer methods and compared using statistical analyses. Recharge estimates derived from unsaturated-zone $\left(R_{\mathrm{UzC}}\right)$ and saturated-zone $\left(R_{\mathrm{SzC}}\right)$ chloride mass balance methods are less variable (interquartile ranges or IQRs are 9.5 and $16.1 \mathrm{~cm} / \mathrm{yr}$, respectively) and more strongly correlated with climatic, hydrologic, land use, and sediment variables than Darcian estimates (IQR $=22.8 \mathrm{~cm} / \mathrm{yr})$. The unit-gradient Darcian estimates are a nonlinear function of moisture content and also reflect the uncertainty of pedotransfer functions used to estimate hydraulic parameters. Significance level is $<0.001$ for nearly all explanatory variables having correlations with $R_{\mathrm{UZC}}$ of $<-0.3$ or $>0.3$. Estimates of $R_{\mathrm{SZC}}$ were evaluated using analysis of variance, multiple comparison tests, and an exploratory nonlinear regression (NLR) model. Recharge generally is greater in coastal plain surficial aquifers, fractured crystalline rocks, and carbonate rocks, or in areas with high sand content. Westernmost portions of the study area have low recharge, receive somewhat less precipitation, and contain fine-grained sediment. The NLR model simulates water input to the land surface followed by transport to ground water, depending on factors that either promote or inhibit water infiltration. The model explains a moderate amount of variation in the data set (coefficient of determination $=0.61$ ). Model sensitivity analysis indicates that mean annual runoff, air temperature, and precipitation, and an index of ground-water exfiltration potential most influence estimates of recharge at sampled sites in the region. Soil characteristics and land use have less influence on the recharge estimates, but nonetheless are significant in the NLR model. (c) 2006 Elsevier B.V. All rights reserved.

\footnotetext{
* Corresponding author.

E-mail address: rwhealy@usgs.gov (R.W. Healy).
} 


\section{Introduction}

Recharge is a major component of the ground-water system and has important implications for shallow ground-water quality. Recharge commonly is estimated at the watershed scale using simple water-budget methods or numerical ground-water flow models. Whereas these methods provide an average recharge estimate for an area, recharge can vary substantially both within and between watersheds because of variations in topography, sediments, and climate. Recharge estimates with site-specific data, such as groundwater levels, ground-water ages, and unsaturated-zone data at points, can complement basin-scale methods. A large number of point estimates over a region, if estimated with reasonable certainty, would indicate the spatial distribution of recharge. The variability of recharge is key to understanding the susceptibility of aquifers to contamination from surface-derived sources.

Recharge may be categorized as diffuse or focused. Diffuse recharge refers to that which occurs over large areas as water from precipitation infiltrates and percolates through the unsaturated zone to the water table. Focused recharge refers to water moving downward to an aquifer from a surface-water body, such as a lake, stream, or canal. Arid regions commonly are characterized by deep water tables, losing streams, and focused recharge. Diffuse recharge usually dominates in humid portions of the United States, where shallow water tables and gaining streams are common. Focused recharge that does occur in humid areas is usually from surface runoff into land-surface depressions or macropores, followed by infiltration.

Diffuse recharge was estimated at 48 locations in southern New Jersey, using a Darcian method based on pedotransfer functions (Baehr et al., 2003). These functions relate hydraulic parameters to easily measured sediment properties such as percent sand, silt, and clay, and are commonly used at regional scales owing to the difficulty and cost of directly measuring hydraulic conductivity (Görres and Gold, 1996; Petach et al., 1991; Soutter and Pannatier, 1996). A companion study (Nolan et al., 2003) evaluated the spatial variability of the recharge estimates and analyzed relations with sediment, landscape, and water-quality data. Multiple linear regression (MLR) was attempted to augment kriging predictions, but correlations between recharge and potential explanatory variables generally were poor. Topographic relief within the study area varied insufficiently to yield strong correlations between recharge estimates and landscape factors. We hypothesize that at a broad scale, such as a multi-state region, increased systematic variation in soil, landscape, and climate variables will facilitate improved correlations with recharge, assuming that recharge can be estimated with reasonable certainty. These correlations can be exploited with empirical models to identify factors that influence recharge and, ultimately, to predict recharge in unsampled areas. Accordingly, the objectives of the research described in this paper are to first obtain consistent estimates of recharge across a large multi-state region, and then to identify factors that significantly influence recharge at this scale.

Recharge in the current study was estimated using ground-water and sediment core data collected by the US
Geological Survey's (USGS's) National Water Quality Assessment (NAWQA) Program, in collaboration with the Ground Water Resources Program (GWRP). Data interpretation was limited to the eastern half of the US because the methods applied are designed to estimate diffuse recharge. Sites in eastern Nebraska and southeastern Texas were included in the analysis because associated aquifers are areally extensive in the east-west direction (Fig. 1). We anticipated that including these sites would enhance correlations between the recharge estimates and climate and landscape variables, for reasons discussed above. The climate of eastern Nebraska is typical of a humid continental region, with a mean annual precipitation of $720 \mathrm{~mm}$ (Fredrick et al., 2006). Mean annual precipitation near sampled sites in southeastern Texas is $1320 \mathrm{~mm}$ (Land et al., 1998).

The study area comprises the following principal aquifers: the glacial aquifer system in the northeast and midwest; the coastal lowlands aquifer system; Piedmont crystalline-rock aquifers; surficial aquifer system and the Floridan aquifer system; and the Northern Atlantic Coastal Plain aquifer system (Fig. 1). Also shown in the figure are boundaries of NAWQA study units for collection of sediment cores and ground-water samples used in the study.

To meet the second objective, we introduce a nonlinear regression (NLR) model, which differs from previous empirical approaches. Previous regression models used MLR to predict recharge based primarily on precipitation data (Delin et al., 2000; Nichols and Verry, 2001; Rangarajan and Athavale, 2000; Sophocleous, 1992) or soil and landscape variables (Nolan et al., 2003). An NLR model (the SPARROW model) was developed to predict nitrogen yield and phosphorus concentrations in streams based in part on streamchannel transport characteristics and spatially referenced watershed data (Smith et al., 1997). The SPARROW model includes linear input terms and multiplicative exponential terms describing either delivery or in-stream loss of contaminants. The nonlinear form seems appropriate to simulate water inputs and factors that proportionally increase or decrease water infiltration. We anticipated that applying NLR to a consistent set of ground-water recharge estimates would help identify factors that affect recharge in the region.

\section{Methods}

Sediment cores and ground-water samples were collected during installation of monitoring wells as part of NAWQA studies shown in Table 1 for principal aquifers of interest. Samples were analyzed by the USGS's National Water Quality Laboratory or in soil physics laboratories (for sediment bulkphysical properties and soil-water extracts) to provide estimates of ground-water recharge by the Darcian method and by chloride-tracer methods applied to the saturated zone and unsaturated-zone pore water. The recharge values were initially compared by examining correlations with spatial data, before developing an empirical model of recharge.

\section{Laboratory analysis of sediment properties}

Sediment cores $0.6 \mathrm{~m}$ long and $5 \mathrm{~cm}$ in diameter were obtained about every $1.5 \mathrm{~m}$ from land surface to the water 


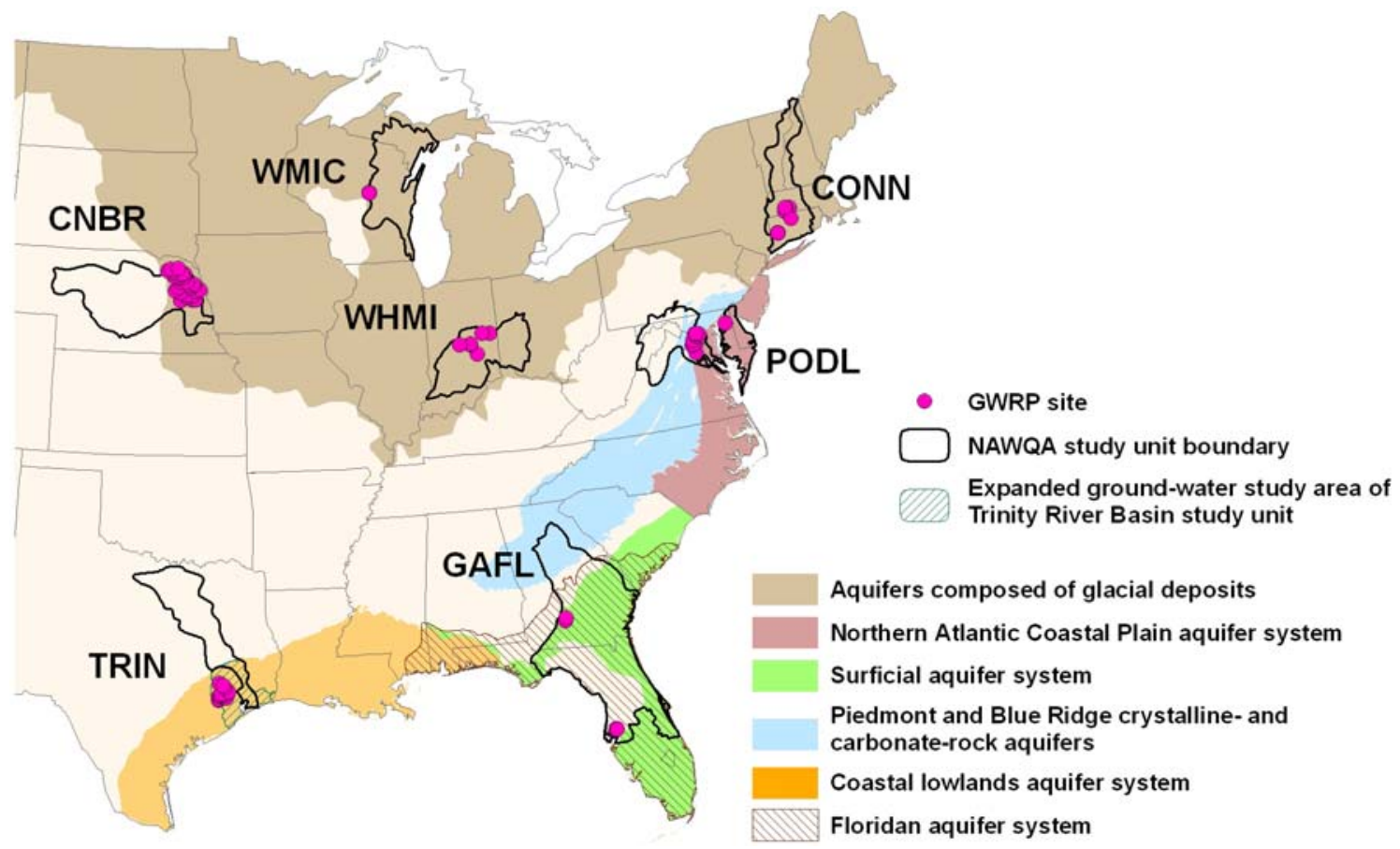

Figure 1 Sediment coring and ground-water sampling locations in the eastern half of the United States, with principal aquifers. Study unit definitions are: CNBR, Central Nebraska Basins; TRIN, Trinity River Basin; WMIC, Western Lake Michigan Drainages; WHMI, White-Miami River Basins; GAFL, Georgia-Florida Coastal Plain; PODL, Potomac-Delmarva River Basins; CONN, Connecticut, Housatonic, and Thames River Basins.

Table 1 Medians of water level and measured unsaturated-zone sediment properties by National Water-Quality Assessment Program study area (excludes irrigated sites)

\begin{tabular}{|c|c|c|c|c|c|c|c|c|}
\hline \multirow[t]{2}{*}{ Identifier } & \multirow[t]{2}{*}{ NAWQA study area } & \multirow{2}{*}{$\begin{array}{l}\text { Number of } \\
\text { sediment } \\
\text { cores }\end{array}$} & \multirow{2}{*}{$\begin{array}{l}\text { Depth to } \\
\text { water, m }\end{array}$} & \multicolumn{3}{|c|}{ Percent } & \multirow{2}{*}{$\begin{array}{l}\text { Bulk } \\
\text { density, } \\
\mathrm{g} / \mathrm{cm}^{3}\end{array}$} & \multirow{2}{*}{$\begin{array}{l}\text { Volumetric } \\
\text { moisture } \\
\text { content, } \\
\mathrm{cm}^{3} / \mathrm{cm}^{3}\end{array}$} \\
\hline & & & & Sand & Silt & Clay & & \\
\hline CNBR & Central Nebraska Basins & 26 & 7.4 & 12.4 & 78.0 & 9.5 & 1.59 & 0.19 \\
\hline TRIN & Trinity River Basin & 29 & 6.4 & 37.4 & 55.1 & 7.3 & 1.57 & 0.16 \\
\hline WMIC & Western Lake Michigan Drainages & 4 & 4.9 & 87.6 & 9.9 & 2.5 & 1.85 & 0.09 \\
\hline WHMI & White-Miami River Basins & 9 & 2.3 & 10.5 & 70.4 & 14.8 & 1.88 & 0.26 \\
\hline GAFL & Georgia-Florida Coastal Plain & 6 & 8.1 & 89.1 & 8.5 & 2.3 & 1.50 & 0.15 \\
\hline PODL & Potomac-Delmarva River Basins & 15 & 4.1 & 66.4 & 30.5 & 2.9 & 1.44 & 0.20 \\
\hline CONN & $\begin{array}{l}\text { Connecticut, Housatonic, } \\
\text { and Thames River Basins }\end{array}$ & 31 & 6.1 & 86.9 & 11.0 & 1.8 & 1.49 & 0.16 \\
\hline
\end{tabular}

table during installation of monitoring wells during the fall of 2002 through the winter of 2004. Nearly 500 cores were obtained (based on multiple sampling depths at each site) and analyzed to determine sand, silt, and clay percentages and bulk density for use with pedotransfer functions; moisture content $(\theta)$ for use in Darcian calculations of water flux; and pore-water chloride concentration for recharge estimation by unsaturated-zone tracer. During data analysis we obtained one recharge estimate by each method per site; for example, the deepest unsaturated-zone water flux from the pedotransfer method was used to infer Darcian recharge. Sand $(>50 \mu \mathrm{m}$ diameter), silt $(2-50 \mu \mathrm{m})$, and clay
$(<2 \mu \mathrm{m})$ fractions were determined by optical diffraction using a Coulter LS-230 particle-size analyzer (Gee and Or, 2002), which measures particles from $0.04 \mu \mathrm{m}$ to $2 \mathrm{~mm}$ in size. Particles greater than $2 \mathrm{~mm}$ were separated with ASTM sieves ranging from 2 to $32.5 \mathrm{~mm}$ and later integrated into the particle-size distribution. Bulk density was determined by the core method (Grossman and Reinsch, 2002), and soil moisture content was determined gravimetrically (Topp and Ferre, 2002). To determine chloride concentration in pore water, the sediment cores were dried and mixed with water at a 1:10 weight ratio. Chloride in the extract solution was determined by ion chromatograph (McMahon et al., 2003). 


\section{Methods of recharge estimation}

Recharge was estimated by the Darcian method and two chloride-tracer methods. Darcian estimates based on pedotransfer functions are referred to in this paper as " $R_{\mathrm{PTF}}$ ". Nonirrigated sites in the eastern half of the US resulted in 76 estimates of $R_{\mathrm{PTF}}, 108$ estimates using chloride in soil pore water as an unsaturated-zone tracer $\left(R_{\mathrm{UzC}}\right)$, and 108 estimates using chloride in ground water as a saturatedzone tracer $\left(R_{\mathrm{SZC}}\right)$. $R_{\mathrm{PTF}}$ estimates could not be obtained at all sites because of missing textural, moisture content, or bulk density data at some locations.

\section{Darcian-pedotransfer method}

In the unsaturated zone, steady vertical flow is described by Darcy's Law:

$q=-K(\theta)\left(\frac{\mathrm{d} \psi}{\mathrm{dz}}+1\right)$

where $q$ is flux density in $\mathrm{cm} / \mathrm{yr}, \mathrm{d} \psi / \mathrm{dz}$ is the matric potential gradient $(\mathrm{cm} / \mathrm{cm})$, and $K(\theta)$ is hydraulic conductivity in $\mathrm{cm} / \mathrm{yr}$. If matric potential is constant with depth, then gravity is the only driving force and $\mathrm{d} \psi / \mathrm{d} z$ is equal to zero. In such cases the magnitude of $q$ equals that of the hydraulic conductivity of the medium at the ambient water content. This approach is called the unit-gradient assumption and has been applied in a number of studies (Chong et al., 1981; Gardner, 1964; Sisson, 1987). Conditions conducive to unit-gradient water flux include location below the depth of the zero flux plane (i.e., the plane of zero hydraulic gradient in the unsaturated zone) and above the capillary fringe and steady flow over time. Under the unit-gradient assumption, a single $K(\theta)$ measurement can indicate long-term average recharge rate in zones of steady downward flow in deep unsaturated zones typical of arid regions (Nimmo et al., 2003). Temporal variability of recharge in such cases is dampened by physical averaging of flow paths (Nimmo et al., 2002). Although the current study sampled shallow unsaturated zones in a comparatively humid climate, dampening of variations in measured soil tension has been observed at shallow depths in central Indiana (Bayless, 2001). Whereas short-term variations in soil tension and moisture content were observed at depths of $0.6 \mathrm{~m}$ or less, measurements were stable at depths of 0.9-1.5 m. Sampling depth for sediment cores in the current study, which includes sites in central Indiana, ranges from about 1 to more than $30 \mathrm{~m}$.

We calculated unit-gradient water fluxes based on data from the Rosetta program (Schaap et al., 1998, 2001). Recharge (downward flux) is the negative of $q$ in Eq. (1), evaluated at the water table. Rosetta consists of hierarchical pedotransfer functions for estimating van Genuchten hydraulic parameters (van Genuchten, 1980) from bulk physical properties, such as bulk density and percentages of sand, silt, and clay. Several unit-gradient water fluxes were calculated for each well location. The deepest water flux that is above the capillary fringe is assumed to represent recharge $\left(R_{\mathrm{PTF}}\right)$.

\section{Chloride tracer methods}

Recharge was estimated by two chloride tracer methods, depending on the source of the chloride data: $R_{\mathrm{UzC}}$ refers to chloride concentration in the unsaturated zone (i.e., pore water from sediment cores used in $R_{\mathrm{PTF}}$ estimates), and $R_{\mathrm{SZC}}$ refers to chloride concentration in the saturated zone (i.e., in ground-water samples from the same wells where coring took place). Thus, there is one $R_{\mathrm{UzC}}$ estimate and one $R_{\mathrm{SzC}}$ estimate per well.

The chloride tracer method compares the rate of chloride deposition on land surface with chloride concentration in the unsaturated zone or saturated zone (Nimmo et al., 2003; Scanlon et al., 2002). Chloride is conservative and its mass inflow to the system must be balanced by mass outflow from the system or by a change in storage of chloride in the unsaturated zone or saturated zone. Under natural conditions, chloride is deposited on the land surface in precipitation and dry deposition. Other natural sources, such as marinederived sediments and saline water in deep aquifers, were determined to contribute insignificant quantities of chloride to the study areas. Chloride may also be applied through the activities of humans, predominantly agricultural practices. Outflow (i.e., recharge) is from the unsaturated zone to the water table. Recharge by this method is described as

$R=1000 \cdot\left(\mathrm{Cl}_{\text {wetdep }}+\mathrm{Cl}_{\text {drydep }}+\mathrm{Cl}_{\text {applied }}\right) / \mathrm{Cl}_{\text {water }}$,

where $R$ is recharge $(\mathrm{cm} / \mathrm{yr})$ based on chloride data from the unsaturated zone $\left(R_{\mathrm{UzC}}\right)$ or saturated zone $\left(R_{\mathrm{SZC}}\right) ; \mathrm{Cl}_{\text {wetdep }}$ and $\mathrm{Cl}_{\text {drydep }}$ are chloride wet and dry atmospheric deposition rates, respectively $\left(\mathrm{mg} / \mathrm{cm}^{2} / \mathrm{yr}\right) ; \mathrm{Cl}_{\text {applied }}$ is the rate at which chloride is applied by humans $\left(\mathrm{mg} / \mathrm{cm}^{2} / \mathrm{yr}\right)$; and $\mathrm{Cl}_{\text {water }}$ is chloride concentration in the unsaturated zone or saturated zone $(\mathrm{mg} / \mathrm{l})$. This equation assumes that all precipitation infiltrates locally. In areas where total infiltration is less than total precipitation because of surface runoff, the chloride tracer recharge value will overestimate true recharge. Infiltration-excess runoff, however, is negligible in the study area (about $7 \%$ of streamflow on average), based on output from a watershed hydrology model (Beven and Kirkby, 1979; Wolock, 1993) at sampled locations. Also, some of the runoff flows onto nearby low-lying areas (i.e., surface water "runon"), where it is a source of recharge.

Values for $\mathrm{Cl}_{\text {wetdep }}$ were obtained through the National Atmospheric Deposition Program (NADP) (National Atmospheric Deposition Program, 2006). Dry deposition of chloride is not measured at NADP sites, but dry and wet deposition data are available for sulfate, nitrate, and ammonia. Wet deposition accounted for $92 \%$, on average, of total depositions of these constituents (coefficient of variation 3\%) in 2002 (US Environmental Protection Agency, 2006). Therefore, it was assumed for purposes of this study that wet deposition also accounted for $92 \%$ of the total chloride deposition (i.e., dry chloride deposition rate, $\mathrm{Cl}_{\text {drydep }}$, was set equal to $8.7 \%$ of the wet rate). The primary source of chloride applied to land surface by humans is agricultural chemicals, in particular muriate potash $(\mathrm{KCl})$, which is applied as a potassium fertilizer for crops. County-level estimates of potassium inputs to land surface have been compiled (Ruddy et al., 2006). For each sampled well, chloride input was estimated by assuming that muriate potash accounted for $90 \%$ of applied potassium (US Department of Agriculture, 2006) and by weighting the county-level fertilizer data on the basis of agricultural land use within 500-m radius circular areas (buffers) around sampled wells; i.e., chloride input was multiplied by the ratio of agricultural land in the well buffer to the total 
agricultural land in the county. For weighting purposes, agricultural lands comprise row crops, small grains, and orchards and/or vineyards. The 500-m radius buffer may not correspond to the actual recharge area of sampled wells, but is a reasonable approximation. NAWQA monitoring wells have shallow screened interval depths (typically from 7 to $9 \mathrm{~m}$ ) and sample recently recharged ground water (typically $<10$ years). Also, land cover is comparatively homogeneous within ground-water land-use studies conducted by NAWQA, such that land use near a well is similar to that elsewhere in the monitoring network.

Estimates of $R_{\text {SzC }}$ used chloride data from wells sampled by NAWQA personnel during 2002-2004. All wells were sampled according to procedures described by Koterba et al. (1995), and dissolved $\mathrm{Cl}$ was analyzed according to procedures in Fishman (1993).

\section{Spatial data for empirical modeling of recharge estimates}

Soil, climate, topographic, and land-use data were compiled for sampled wells using a geographic information system (GIS) to generate explanatory variables for empirical modeling of recharge. Land-use data categories were compiled as percentages of well buffers, and the remaining variables (excluding presence-or-absence type variables) were compiled as weighted averages within buffers. Selected variables described here are significantly correlated with recharge estimates. A complete list (including evapotranspiration, for example) is provided in Appendix 1.

Soil data came from the US Department of Agriculture's State Soil Geographic (STATSGO) maps, which are produced at $1: 250,000$ scale by generalizing soil survey data (US Department of Agriculture, 1994). Initially compiled at 1$\mathrm{km}$ resolution (Wolock, 1997) by converting soil mapping units to grid cells in a GIS, the STATSGO data were recompiled at $100-\mathrm{m}$ resolution in the current study to simulate local-scale variation in soil properties.

Mean annual precipitation and temperature for 1980-97 were derived from DAYMET, a climate model that predicts daily temperature, precipitation, humidity, and radiation based on digital elevation data and observed values of precipitation and minimum and maximum temperature from weather stations (Thornton and Running, 1999). Several hydrologic factors were compiled to see if local recharge estimates were correlated with flow characteristics estimated by watershed models. Estimated percentage of Hortonian overland flow in total streamflow was calculated for the entire country using $5-\mathrm{km}$-grid cells with TOPMODEL, a rainfall-runoff watershed model that integrates climate and landscape characteristics (Wolock, 2003d). TOPMODEL simulates water flow in a watershed beginning from when water enters the watershed as precipitation until it exits as streamflow. Hortonian overland flow is generated when precipitation exceeds the infiltration capacity of the soil.

Base flow is the component of streamflow attributable to ground-water discharge to streams. The base-flow index (BFI) is the ratio of base flow to total streamflow, expressed in percent. These percentages were determined on a $1-\mathrm{km}$ grid by interpolating from point BFI values at USGS stream gages (Wolock, 2003a). The point values were computed from time series of historical daily streamflow values using an automated hydrograph separation computer program (Wolock, 2003c). Mean annual base flow was estimated by multiplying the grid of BFI values by a grid of mean annual runoff values (Gebert et al., 1987). Computation of the subsurface-flow contact time index is based on a simple conceptualization of the lateral movement of both shallow and deep saturated subsurface flow toward a stream (Vitvar et al., 2002). The index was calculated using 1:250,000-scale digital elevation maps (US Geological Survey, 1987) and the STATSGO data describing subsurface hydraulic characteristics. Subsurfaceflow contact time increases as the soil porosity and ridgeto-valley flow length increase, and decreases as topographic slope and saturated hydraulic conductivity increase. The index is intended to describe relative differences in subsurface contact time among watersheds, and agreed well with estimates of mean baseflow residence time derived from isotopic data (Vitvar et al., 2002).

Topographic wetness index (TWI) quantifies the effect of topography on the redistribution of moisture within a watershed. High values of TWI can indicate locations within a watershed where the water table intersects the land surface. Hence, TWI values indicate the potential caused by the effects of topography for ground-water exfiltration. The TWI index is given by $\ln (a / \tan \beta)$, where $a$ is the upslope area per unit contour length and $\tan \beta$ is the slope gradient along which drainage occurs. TWI values were computed at $1-\mathrm{km}$ resolution from digital elevation data (Wolock and McCabe, 1995).

Land-use percentages are based on a combination of 30 $m$ resolution National Land Cover Data (NLCD 92) derived from 1992 Landsat imagery (Vogelmann et al., 2001) and USGS Land Use and Land Cover (LULC) data derived from 1970 s to 1980 s aerial photography (US Geological Survey, 1990). Residential, orchards/vineyards/other, and tundra categories of NLCD 92 data were reclassified using LULC data because some land covers are difficult to distinguish with satellite imagery (Nakagaki and Wolock, 2005).

\section{Statistical methods}

Statistical analyses of recharge estimates consisted of summary statistics, Spearman correlations, and analysis of variance (ANOVA) and multiple comparison tests (MCTs) on ranked data to assess relations with potential explanatory variables. Nonlinear regression (NLR) was used to identify factors - in a multi-variate context - that most influence recharge for the sites studied. Recharge depends not on a single factor but on the simultaneous influence of several factors representing climate, soil, and landscape processes. These interactions cause some variables, such as TWI, to emerge as significant in NLR even though they are insignificant in univariate correlations. For this reason, additional variables not shown in Table 2 were screened with the NLR model, including all available STATSGO, NLCDe 92, National Resources Inventory (US Department of Agriculture, 1995), and water-use variables (Solley et al., 1998) (Appendix 1). Over 100 variables were tested in the NLR model.

The NLR model has a multiplicative structure with explanatory variables representing water input (precipitation) and factors that either enhance or inhibit 
Table 2 Univariate correlations between estimated recharge and potential explanatory variables screened in the nonlinear regression model $(L$, length; $T$, time; \%, percent)

\begin{tabular}{|c|c|c|c|}
\hline \multirow[t]{2}{*}{ Variable } & \multicolumn{3}{|c|}{ Spearman correlation coefficient ( $p$-value) } \\
\hline & $\begin{array}{l}\text { Chloride tracer in } \\
\text { saturated zone }\left(R_{\mathrm{SZC}}\right)^{\mathrm{a}}\end{array}$ & $\begin{array}{l}\text { Chloride tracer in } \\
\text { unsaturated zone }\left(R_{\mathrm{UZC}}\right)^{\mathrm{b}}\end{array}$ & $\begin{array}{l}\text { Darcian-pedotransfer } \\
\text { method }\left(R_{\mathrm{PTF}}\right)\end{array}$ \\
\hline \multicolumn{4}{|l|}{ Climate and hydrology } \\
\hline Mean annual base flow, $L / T$ & 0.426 & 0.437 & $0.228(0.050)$ \\
\hline Hortonian overland flow, \% & -0.554 & -0.443 & $-0.136(0.250)$ \\
\hline Mean annual runoff $(1951-80), L$ & 0.329 & 0.362 & $0.207(0.074)$ \\
\hline Subsurface flow contact time, $T$ & -0.305 & -0.357 & $-0.046(0.697)$ \\
\hline \multicolumn{4}{|l|}{ Land cover and management } \\
\hline Orchards/vineyards/other, \% & $0.111(0.256)$ & 0.357 & $0.086(0.461)$ \\
\hline Woody wetlands, $\%$ & 0.256 & $0.304(0.001)$ & $0.041(0.727)$ \\
\hline Irrigated acres, micro-irrigation systems, $L^{2}$ & $0.175(0.073)$ & 0.443 & $0.050(0.670)$ \\
\hline Irrigated acres, surface-irrigation systems, $L^{2}$ & -0.338 & -0.346 & $-0.208(0.074)$ \\
\hline \multicolumn{4}{|l|}{ Measured sediment properties } \\
\hline Sand above water table, $\%$ & 0.256 & $0.307(0.001)$ & $0.146(0.207)$ \\
\hline Silt above water table, $\%$ & -0.258 & -0.320 & $-0.159(0.171)$ \\
\hline \multicolumn{4}{|l|}{ STATSGO soil properties or groups } \\
\hline Soil hydrologic group A, \% & 0.369 & 0.420 & $0.187(0.107)$ \\
\hline Soil hydrologic group A/D, \% & 0.294 & 0.406 & $0.099(0.399)$ \\
\hline Soil loss tolerance factor & -0.392 & -0.376 & $-0.205(0.078)$ \\
\hline Soil shrink-swell potential & -0.374 & -0.322 & $-0.224(0.054)$ \\
\hline Vertical permeability, $L / T$ & 0.319 & 0.382 & $0.142(0.225)$ \\
\hline Permeability of least permeable layer, $L / T$ & 0.353 & 0.366 & $0.083(0.480)$ \\
\hline Available water capacity, fraction & $-0.124(0.207)$ & -0.336 & $-0.187(0.109)$ \\
\hline Organic matter, \% by weight & $0.237(0.014)$ & 0.329 & $-0.040(0.732)$ \\
\hline Sand, \% & $0.201(0.038)$ & 0.362 & $0.173(0.139)$ \\
\hline Silt, \% & $-0.148(0.131)$ & -0.322 & $-0.153(0.190)$ \\
\hline Clay, \% & $-0.247(0.011)$ & -0.337 & $-0.195(0.098)$ \\
\hline Soil $<8 \mathrm{~cm}$ in size and passing a $0.074 \mathrm{~mm}$ sieve & $-0.230(0.018)$ & -0.351 & $-0.200(0.086)$ \\
\hline Entisols, \% & $0.217(0.026)$ & 0.320 & $-0.079(0.500)$ \\
\hline Histosols, \% & 0.407 & 0.407 & $0.101(0.389)$ \\
\hline
\end{tabular}

water transport to ground water. After the exhaustive screening of variables in Appendix 1 , those that remain in the model either are significant at the 0.05 level or are considered conceptually important. The explanatory variables are organized into water-input and transport components described by

$R_{i}=b+l_{i} \cdot T_{i}+\varepsilon_{i}$,

where

$I_{i}=\sum_{n=1}^{N} \beta_{n} X_{n, i}$

$T_{i}=\exp \left(\sum_{j=1}^{J} \alpha_{j} Z_{j, i}\right)$

and

$b=$ intercept

$R_{i}=$ natural log of "measured" recharge at sampling point $i$, from estimation by measured chloride tracer in the saturated zone $\left(R_{\mathrm{SzC}}\right), \ln (\mathrm{cm} / \mathrm{yr})$
$I_{i}=$ total water input at $i$

$T_{i}=$ proportional increase or decrease in water input at $i$ due to transport factors

$X_{n, i}=$ normalized water input $n$ at $i$, such as precipitation or irrigation

$Z_{j, i}=$ normalized transport factor $j$ at $i$

$\beta_{n}=$ coefficient for water input variable $n$

$\alpha_{j}=$ coefficient for transport factor $j$

$\varepsilon_{i}=$ model error at sampling point $i$

Recharge estimates were natural log transformed for use in the NLR model, because this resulted in more constant variance of model errors across the range of predictions, as well as normally distributed errors. Predicted values of recharge then were back transformed into real space for plotting purposes using a "smearing" estimate (Helsel and Hirsch, 1992). The smearing estimator converts log-transformed values to original units ( $\mathrm{cm} / \mathrm{yr}$ in this case) using a bias-correction factor, and is robust because it makes no assumption regarding the distribution of regression residuals. 
Independent variables $\left(X_{n, i}\right.$ and $\left.Z_{j, i}\right)$ were normalized by dividing by their mean values, so that regression coefficients within each model component $\left(I_{i}\right.$ and $\left.T_{i}\right)$ can be compared to ascertain the relative influence of variables on recharge. Coefficients cannot be compared between components, however, because $I_{i}$ is linear and $T_{i}$ is exponential. To enhance comparability of all variables, we evaluated model sensitivity by relating changes in predicted recharge to incremental changes in the independent variables. We computed "relative sensitivity" (RS) as the absolute value of percent change in recharge, in units of $\ln (\mathrm{cm} / \mathrm{yr})$, for a $1 \%$ change in an independent variable while holding the remaining variables constant.

\section{Results and discussion}

Medians of measured sediment texture, bulk density, and volumetric moisture content are summarized by NAWQA study area in Table 1. Sediment-texture data reflect regional vari- ations in unsaturated-zone characteristics. The median silt content of sediment cores from WHMI and CNBR is $70 \%$ and $78 \%$, respectively (see Table 1 for definition of NAWQA study area acronyms). Wells in CNBR are completed in shallow glacial sand lenses and WHMI wells are in relatively impermeable glacial till. In contrast, sediment cores from WMIC, GAFL, PODL, and CONN contain on average 66-89\% sand. GAFL wells are completed in the Coastal Plain surficial aquifer and in the Floridan aquifer; PODL wells are completed in the coastal plain sand and gravel aquifer and in the Piedmont and Blue Ridge aquifer; and WMIC and CONN wells are in sand and gravel aquifers in valley fill glacial outwash. Median sand and silt contents of TRIN cores, in the coastal lowlands, are somewhat less ( $37 \%$ and $55 \%$, respectively).

\section{Statistical analysis of recharge estimates}

Recharge estimates for all sites are shown in Appendix 1. Estimates of $R_{\mathrm{PTF}}, R_{\mathrm{SZC}}$, and $R_{\mathrm{UZC}}$ are highly skewed
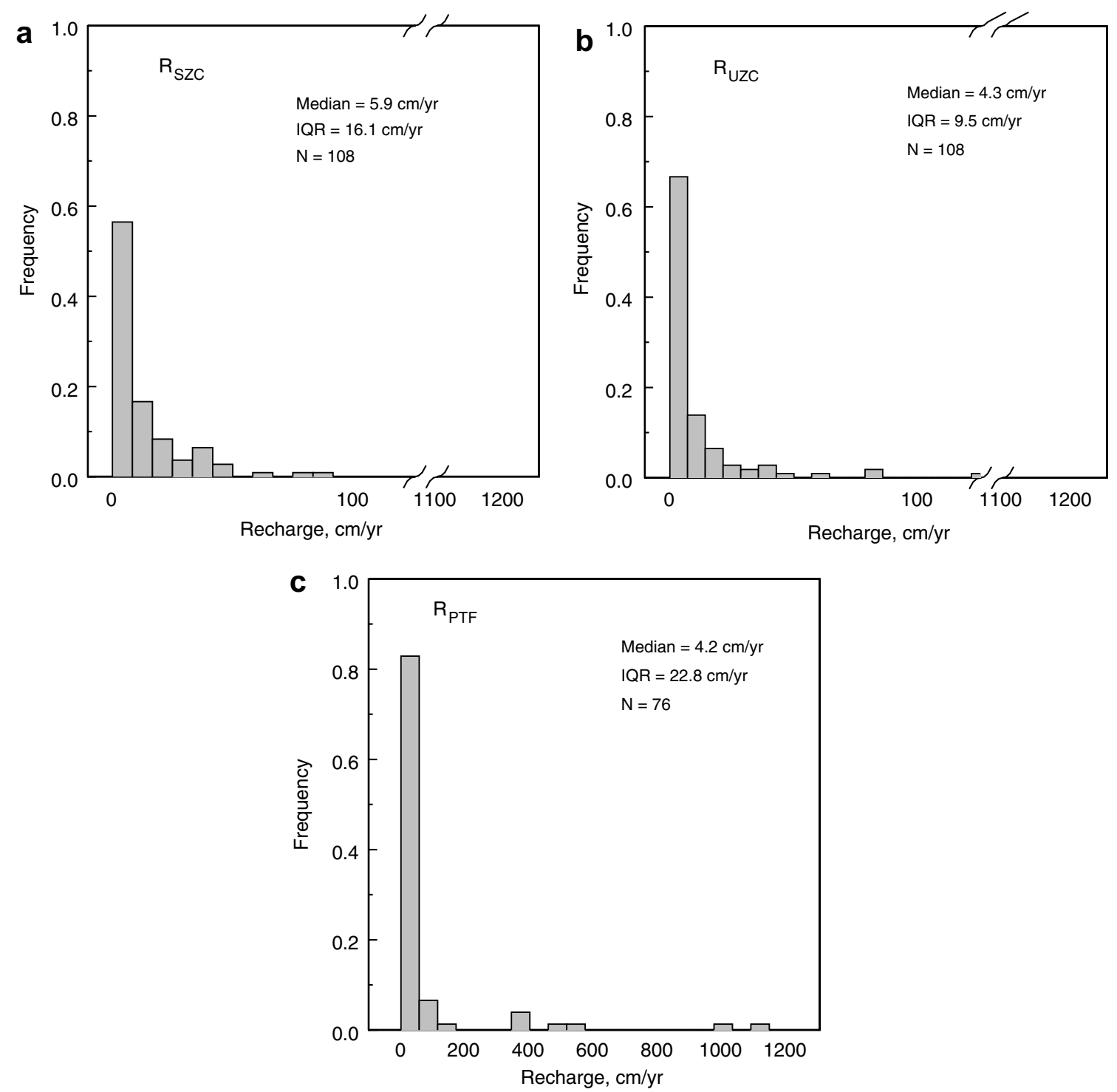

Figure 2 Histograms showing distributions of recharge estimates by (a) saturated-zone chloride tracer $\left(R_{\mathrm{SZC}}\right)$, (b) unsaturatedzone chloride tracer $\left(R_{\mathrm{UZC}}\right)$, and $(\mathrm{c})$ the Darcian-pedotransfer method $\left(R_{\mathrm{PTF}}\right)$. 
(Fig. 2). Statistical distributions of $R_{\mathrm{SZC}}$ and $R_{\mathrm{UZC}}$ (Fig. 2a and $\mathrm{b}$, respectively) appear similar, but the latter has a somewhat lower median $(4.3 \mathrm{~cm} / \mathrm{yr}$ compared with $5.9 \mathrm{~cm} / \mathrm{yr}$ for $\left.R_{\mathrm{SZC}}\right)$. The greater median and variability of $R_{\mathrm{SZC}}$ (IQR $=16.1$ versus $9.5 \mathrm{~cm} / \mathrm{yr}$ for $\left.R_{\mathrm{UzC}}\right)$ may reflect preferential flow, which causes saturated-zone chloride estimates of recharge to exceed unsaturated zone estimates by as much as two orders of magnitude (Scanlon et al., 2002). Saturated zone estimates integrate water fluxes over areas ranging from a few to several thousand square meters, areas much larger than those sampled by unsaturated zone methods (Scanlon et al., 2002). Hence, the $R_{\mathrm{SzC}}$ method is more likely than the $R_{\text {Uzc }}$ method to capture preferential flow, which can occur as focused recharge beneath small-scale topographic depressions at lowland sites that received surfacewater run-on (Delin et al., 2000). In contrast, $R_{\mathrm{UzC}}$ and $R_{\mathrm{PTF}}$ are point estimates. The IQR of $R_{\text {PTF }}(22.8 \mathrm{~cm} / \mathrm{yr})$ is the highest of the three methods, indicating greater variability (Fig. 2c). $R_{\mathrm{PTF}}$ statistics are influenced by the maximum value of $1140 \mathrm{~cm} / \mathrm{yr}$. Although such a high value might result from focused recharge in topographically low lying areas, it could also result from measurement inaccuracies. The $R_{\text {PTF }}$ estimates are highly uncertain because $K(\theta)$ is sensitive to small changes in moisture content, and because the estimated hydraulic parameters are subject to the uncertainty of the Rosetta model. The latter uncertainty arises for several reasons: the estimated hydraulic properties are a function of observed matric potential and soil texture; the number of samples in the Rosetta database varies from about 200 to 2100 depending on the hydraulic property of interest; and, silt and clay textures are somewhat underrepresented in the Rosetta database (Schaap et al., 2001).

Recharge estimates by chloride tracer are significantly correlated with environmental factors (Table 2). Variables with univariate correlations of $<-0.3$ or $>0.3$ for $R_{\mathrm{UzC}}$ are shown in the table. Spearman correlations are positive for mean annual base flow, runoff, and factors related to coarse-grained soils (such as percent sand and "soil hydrologic group A'"); and negative for Hortonian overland flow and factors related to fine-grained soils (such as percent silt and clay). Soil hydrologic group A is described as "deep, well drained to excessively drained sands or gravels"'; group $A / D$ indicates soils that have a "very slow rate of water transmission" in their natural condition but that behave as group A soils when artificially drained (US Department of Agriculture, 2001).

Correlations generally are strongest for $R_{\mathrm{UzC}}$, with $p \leqslant 0.001$ for all variables shown in Table 2 . The maximum positive correlation by this method is 0.443 . The maximum correlation overall $(-0.554)$ was obtained with $R_{\mathrm{SzC}}$. Although correlations with $R_{\mathrm{SzC}}$ generally are weaker, more than half of these have significance level $<0.01$. Weaker correlations with recharge estimates by this method may reflect preferential flow. Estimates of $R_{\mathrm{PTF}}$ yield the weakest correlations with spatial data (Table 2 ). Only two variables approached the 0.05 significance level: base flow $(p=0.050)$ and shrink-swell potential $(p=0.054)$.

\section{Factors influencing recharge in the study area}

The remainder of the paper focuses on $R_{\mathrm{SZC}}$, which is significantly correlated with several potential explanatory vari- ables in Table 2 , has intermediate variability $(I Q R=16.1)$, and performed better than $R_{\mathrm{UZC}}$ and $R_{\mathrm{PTF}}$ in subsequent empirical models. Results of ANOVA and Tukey's test on ranked data indicate that NAWQA study areas containing coarse-grained or fractured aquifers or with high sand content (those marked " $A$ " or "AB" in Fig. 3) - with the exception of CONN - have significantly greater recharge than their westernmost counterparts (those marked "BC" or " $C$ ", such as CNBR and TRIN). In the figure, study areas with the same letter are not significantly different at the 0.05 level. Some of the study areas marked " $A$ " and AB", contain sand and gravel aquifers (PODL and GAFL coastal plain surficial aquifers), fractured crystalline rocks (PODL Piedmont and Blue Ridge), or carbonate rocks with karst features (Floridan aquifer in GAFL), which are highly transmissive. This makes sense, because the same hydrogeologic characteristics that lead to high transmissivities in the saturated zone also promote high recharge rates through the unsaturated zone.

Estimates of $R_{\mathrm{SZC}}$ in WMIC apparently reflect the high sand content (median $=87.6 \%$ ) of coarse-grained glacial deposits, although it is hard to generalize because only four estimates were obtained. WHMI is in glacial deposits comprising fine-grained sediment (median silt content $=70.4 \%$ ), but recharge in the area is enhanced by the presence of numerous tile drains that convey excess water from agricultural fields and thus lower the water table. In the absence of drains, the water table would rise to land surface and could reject additional recharge. We anticipated that CONN sites (median sand content $=86.9 \%$ ) would have greater median recharge than shown in Fig. 3; these estimates may show effects from road salt, which was assumed negligible compared with fertilizer inputs of chloride. The remaining study areas (TRIN and CNBR) contain fine-grained sediments (median silt content $=55 \%$ and $78 \%$ ) and have comparatively low recharge (Table 1 ).

Using the NLR model and subsequent sensitivity analysis, we identified factors that most influence the $R_{\mathrm{szc}}$ estimates. The model explains a moderate amount of variation in the data set, based on the coefficient of determination $\left(R^{2}\right)$ of 0.61 , and the standard error of regression is $0.942 \mathrm{ln}(\mathrm{cm} /$ $\mathrm{yr}$ ). A plot of predicted versus observed or "measured" recharge $\left(R_{\mathrm{SzC}}\right)$ indicates that the overall model fit is reasonable (Fig. 4a). A probability plot indicates that the residuals are normally distributed, which satisfies regression assumptions regarding hypothesis testing for significance of model coefficients (Fig. 4b).

The model comprises water input and transport factors that promote or inhibit transfer of water through the unsaturated zone to the water table. Ten of these are significant at the 0.05 level, and the significance of TWI and precipitation approaches 0.05 (Table 3). This differs from the MLR model attempted for southern New Jersey, for which only measured percent clay $(p=0.045)$ was significant at the 0.05 level (Nolan et al., 2003). The regional scope of the current study facilitates systematic variation in climate and landscape variables, which promotes correlations with recharge. In particular, regional climate patterns and flow processes drive the observed correlations, which are exploited by the NLR model. The NLR model differs from an earlier empirical approach that modeled recharge globally (Doll et al., 2002). They assigned values by expert judg- 


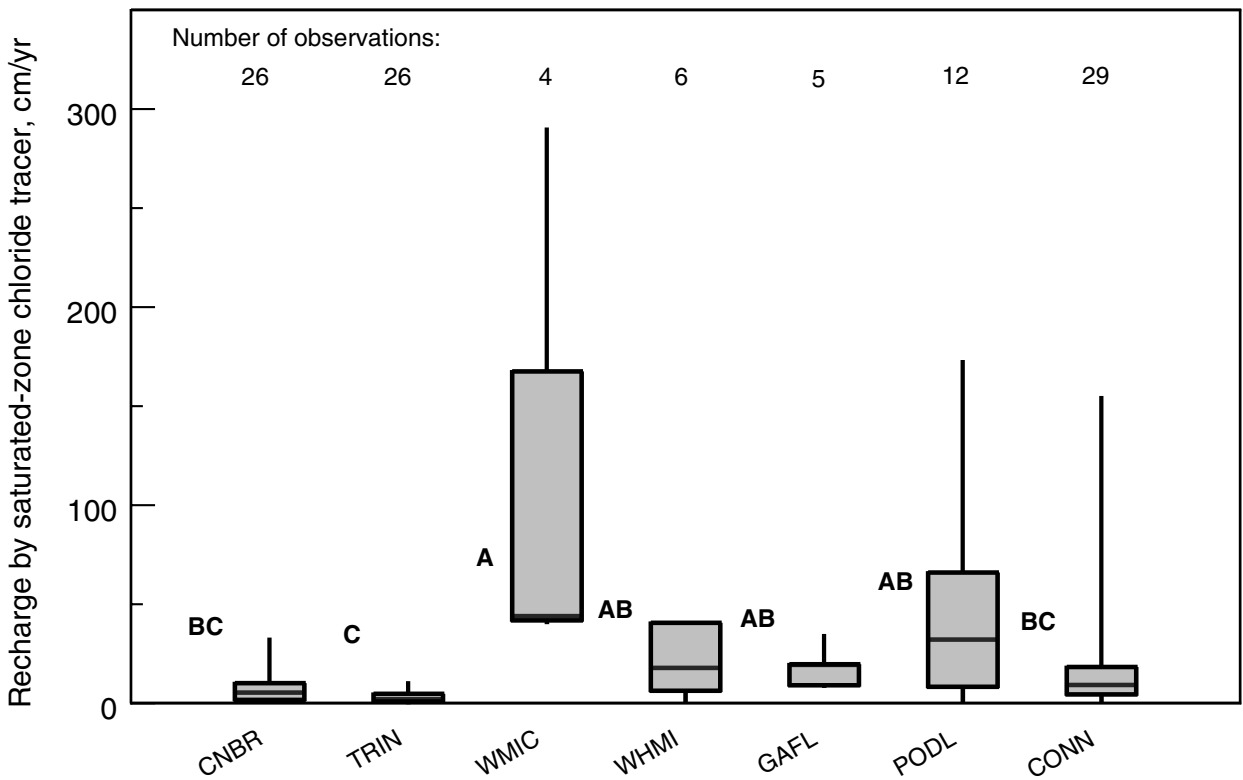

Figure 3 Recharge estimates by saturated-zone chloride tracer $\left(R_{\mathrm{SZC}}\right)$ for study units of the National Water-Quality Assessment Program, proceeding from west to east in the region. Study unit definitions are: CNBR, Central Nebraska Basins; TRIN, Trinity River Basin; WMIC, Western Lake Michigan Drainages; WHMI, White-Miami River Basins; GAFL, Georgia-Florida Coastal Plain; PODL, Potomac-Delmarva River Basins; CONN, Connecticut, Housatonic, and Thames River Basins. In the figure, study areas with the same letter (e.g., "A") are not significantly different at the 0.05 level.
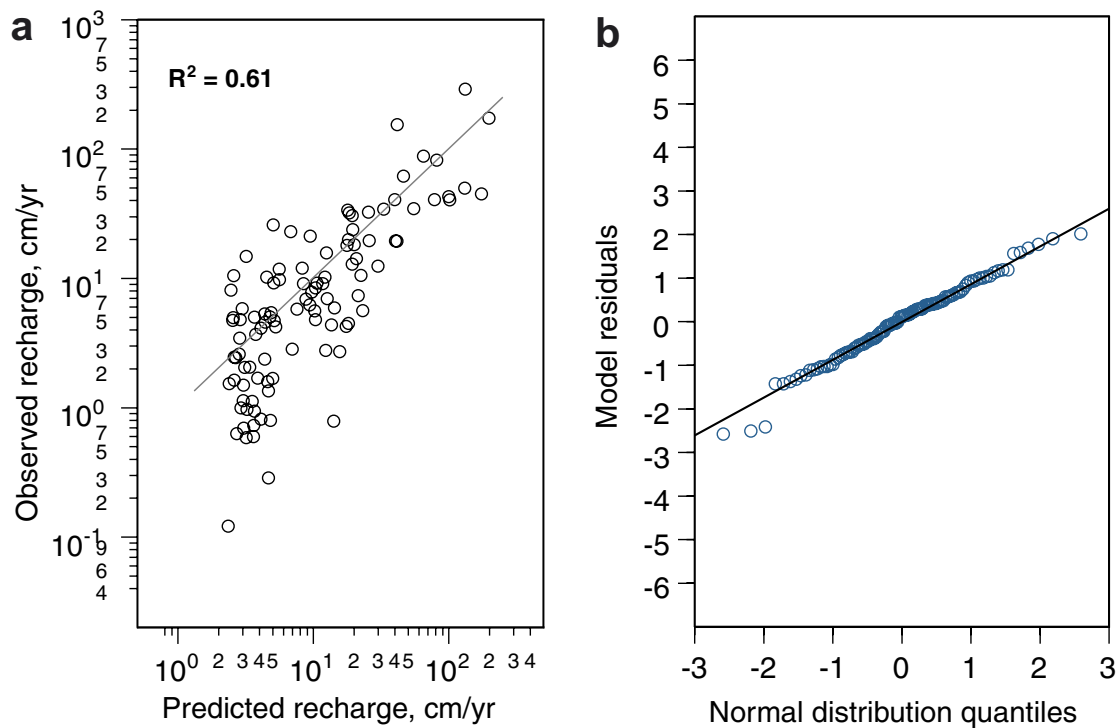

Figure 4 (a) Observed recharge versus that predicted by the nonlinear regression model. Observed recharge refers to estimates by saturated-zone chloride tracer $\left(R_{\mathrm{SzC}}\right)$. (b) Quantile plot of model residuals. Natural logarithms of model residuals are shown.

ment for factors representing the fraction of total runoff of land areas delivered as recharge, and checked results in iterative fashion. In contrast, NLR transport factors are weighted automatically by model coefficients during calibration.

Factors are shown in Table 3 in decreasing order of influence for components $I_{i}$ and $T_{i}$ of the NLR model. Irrigation variables are insignificant in these regressions, so Eq. (4) reduces to a single water-input variable (precipitation). Relative sensitivity values indicate that, overall, mean annual runoff $(\mathrm{RS}=1.1)$, air temperature $(\mathrm{RS}=0.80)$, and precipitation $(R S=0.68)$, and TWI $(R S=0.63)$ most influence recharge at sampled sites in the region. For example, recharge predicted by Eq. (3) increases by $0.68 \%$ for a $1 \%$ increase in mean annual precipitation. The comparatively large influence of the precipitation variable and positive coefficient sign are consistent with prior regression models. Annual precipitation was the most important variable in a MLR model that also included maximum soil-water storage, shallow depth to water table, and spring rainfall rate as 
Table 3 Parameters of nonlinear regression model for ground-water recharge

\begin{tabular}{lllll}
\hline Model parameter & Units ${ }^{\mathrm{a}}$ & Estimated coefficient $^{\mathrm{b}}$ & Significance level $(p)^{\text {Relative sensitivity }^{\mathrm{c}}}$ \\
\hline Intercept & $\ln (\mathrm{cm} / \mathrm{yr})$ & 0.437 & 0.174 & na \\
Water input $(\beta)$ & & & 0.68 \\
Mean annual precipitation & $\mathrm{cm} / \mathrm{yr}$ & 21.4 & 0.0838 & \\
Water transport factor $(\alpha)$ & & & 1.1 \\
Mean annual runoff & $\mathrm{cm} / \mathrm{yr}$ & -1.71 & 0.0007 & 0.80 \\
Mean annual temperature & ${ }^{\circ} \mathrm{C}$ & -1.25 & 0.0002 & 0.63 \\
Topographic wetness index & $\ln (\mathrm{m})$ & -0.969 & 0.0547 & 0.54 \\
Hortonian overland flow & $\%$ & -0.827 & 0.0032 & 0.30 \\
Inceptisols & $\%$ & 0.438 & 0.0053 & 0.30 \\
Hydric soils & $\%$ & 0.426 & 0.0059 & 0.28 \\
Measured sand above water table & $\%$ & 0.398 & 0.0081 & 0.21 \\
Subsurface flow contact time & days & 0.308 & 0.0019 & 0.10 \\
Ultisols & $\%$ & 0.147 & 0.0007 & 0.10 \\
Residential land use ${ }^{\mathrm{d}}$ & $\%$ & -0.147 & 0.0411 & 0.08 \\
Soil hydrologic group A & $\%$ & 0.114 & 0.0165 & 0.05 \\
Wetlands & & -0.0674 & 0.150 &
\end{tabular}

na: Not applicable; $\beta$ and $\alpha$ correspond to parameter coefficients in Eqs. (4) and (5), respectively.

a Original units before normalization of independent variables.

b After normalization; all units of independent variables are dimensionless after dividing by their mean values. Coefficients within the exponential component of the model $(\alpha)$ are directly comparable.

c Absolute value of percent change in predicted recharge in units of $\ln (\mathrm{cm} / \mathrm{yr})$, for $1 \%$ change in an independent variable.

d NLCDe 92 categories 25 (residential without forest) and 26 (residential with forest).

e NLCDe 92 categories 91 (woody wetlands) and 92 (emergent herbaceous wetlands).

explanatory variables (Sophocleous, 1992). Prior researchers observed high correlations between recharge and seasonal precipitation for hydrogeological provinces in India (Rangarajan and Athavale, 2000). Seasonal precipitation amounts were strongly related to recharge in glaciated sediments of north-central Minnesota (Nichols and Verry, 2001). Based on these earlier results, seasonal variables representing spring (March-May), summer (June-August), fall (September-November), and winter (December-February) precipitation were tested with the NLR model, but were statistically insignificant.

Transport factors proportionally increase or decrease water inputs, as indicated by the sign of the model coefficient, in nonlinear fashion. For example, mean annual temperature has a negative coefficient sign, indicating that as temperature increases, recharge decreases, likely because of increased potential for evapotranspiration. Temperature generally increases from north to south in the region; TRIN and GAFL have the warmest mean annual temperature among sampled study areas.

Some model coefficients have a different sign than obtained with univariate correlations. The univariate correlation coefficient for mean annual runoff is positive (Table 2), but this factor has a negative coefficient sign in the NLR model (Table 3). The positive sign in the univariate case is reasonable because runoff by this method (Gebert et al., 1987 ) is calculated as stream flow divided by basin area. Base flow is a component of stream flow. The base-flow index (used to compute base flow) is assumed to represent, over the long term, the percentage of natural ground-water discharge to streams (Wolock, 2003b). Long-term discharge should resemble long-term average natural ground-water recharge. In the multi-variate NLR model, however, runoff appears to explain residual variation in recharge that is not accounted for by other variables in the model. Factors such as precipitation and sandy, well-drained soils represent infiltration and are positively related to recharge as well. Therefore in the multi-variate case, runoff appears more related to overland water movement to streams, which is expected to have a negative relation with recharge. The negative sign for Hortonian overland flow $(R S=0.54)$ provides additional evidence of such a relation.

Similarly, subsurface contact time (positive coefficient sign, $\mathrm{RS}=0.21$ ) may explain residual variation in the NLR model, given that TWI is also in the model. Topographic wetness index (negative sign, RS $=0.63$ ) is a terrain metric that depends on drainage area and slope and indicates the potential for ground-water exfiltration. Thus, high values of TWI represent ground-water discharge areas, and would be expected to be inversely related to recharge. Subsurface contact time is positively related to TWI and negatively related to the lateral hydraulic conductivity of the aquifer (Vitvar et al., 2002). Because both contact time and TWI are in the model, the former may reflect lateral residence time, with greater times associated with more opportunity for vertical movement of infiltrating water.

Soil characteristics, sediment texture, and land use have small RS values ( 0.30 or less) and, therefore, less influence on the recharge estimates. Some of these factors likely represent combined effects of sediment texture and climate on recharge. Hydric soils (positive sign, $\mathrm{RS}=0.30$ ) represent saturated, flooded, or ponding conditions and commonly are anaerobic near the surface. Ultisols $(R S=0.10)$ are highly weathered soils that contain oxidized iron and alumi- 


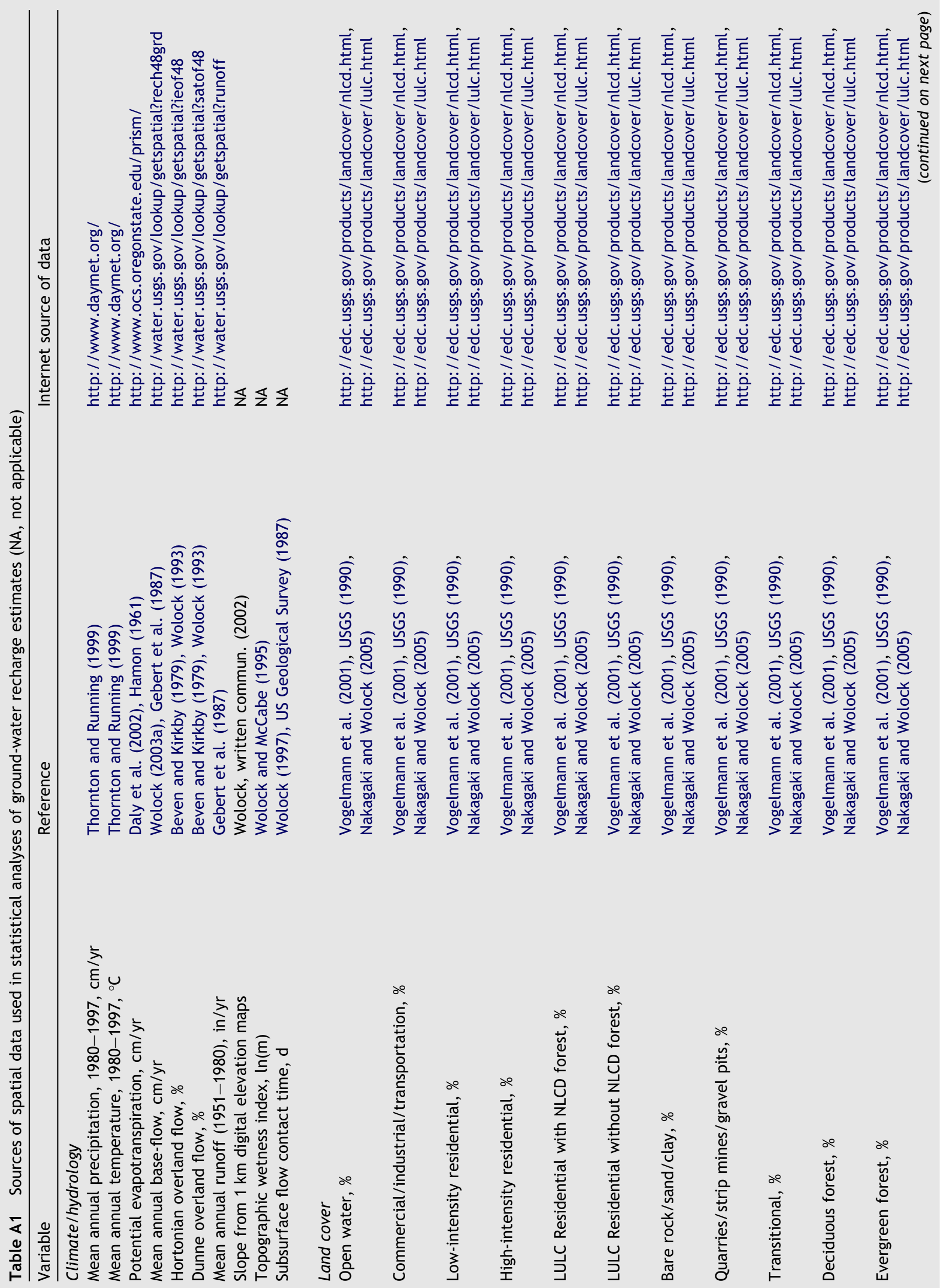




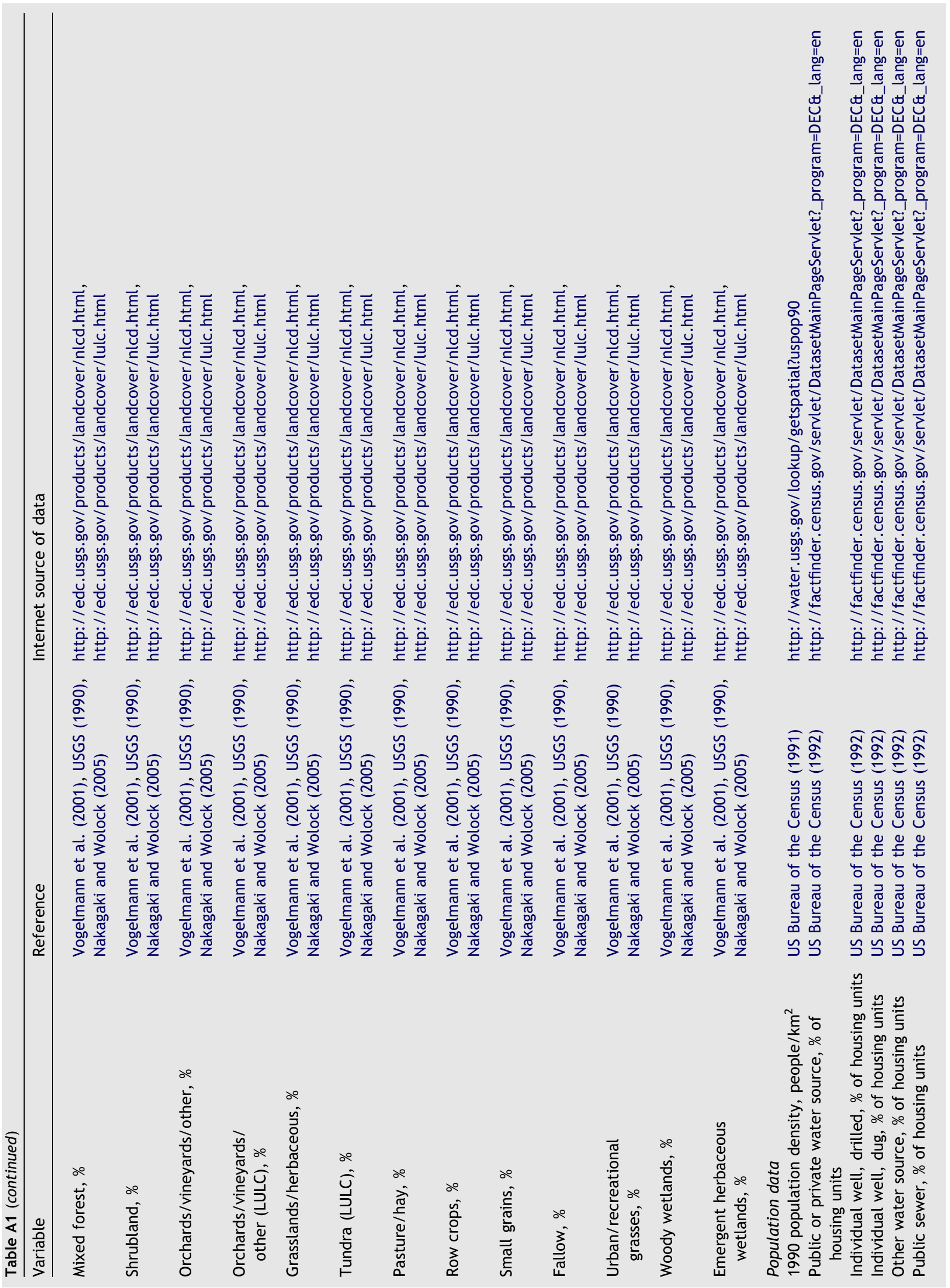




\section{๗) \\ की \\ 岀 \\ है

出芯

कू कू कू

은

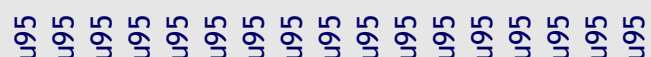

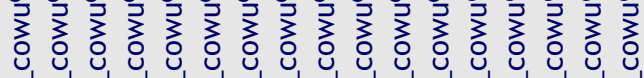

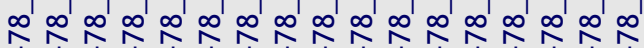

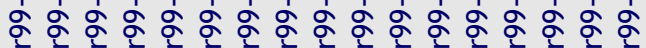

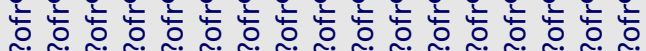
ত

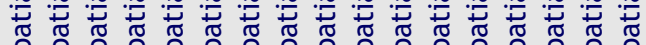

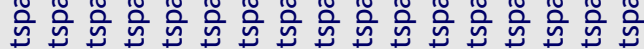

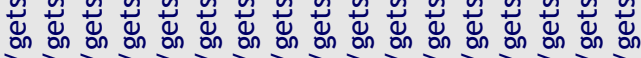

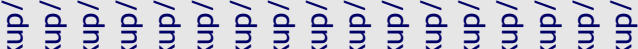

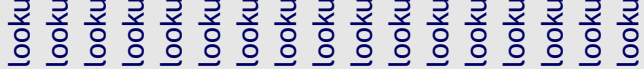

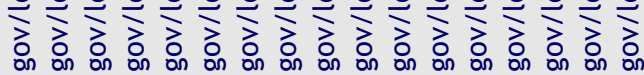

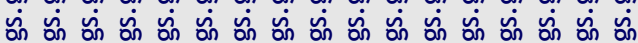

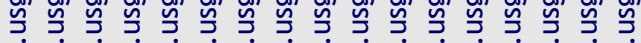

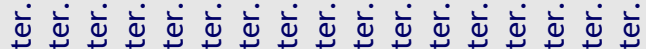
3 촌.

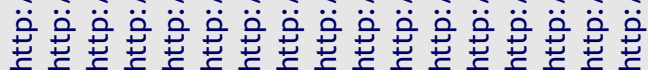

สิส

ूू

气ิ 气ั้

凹

$\stackrel{Ð}{ \pm}$

额

ว

站 站

气ั

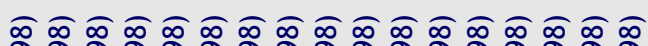

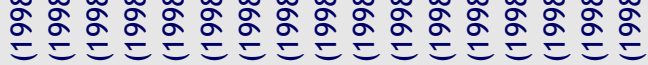

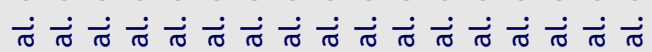

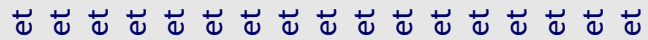

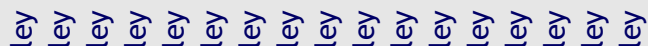

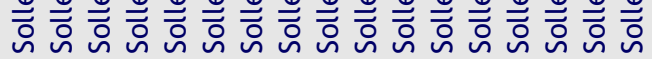

告

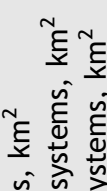

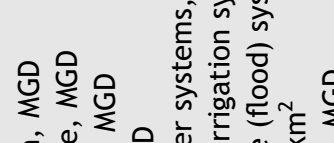

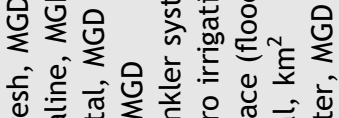

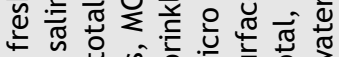

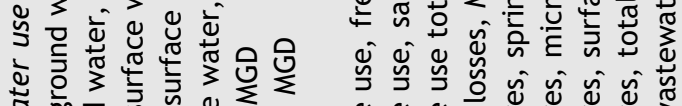
实 के

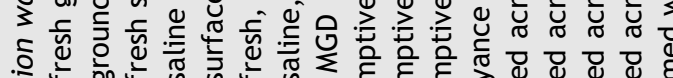

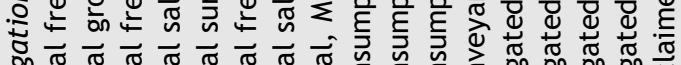

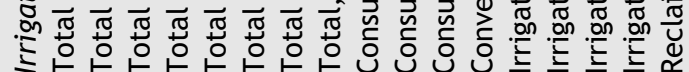

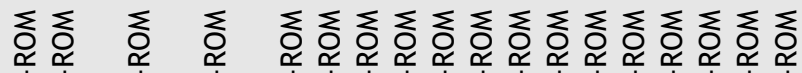

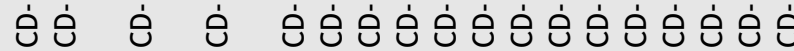

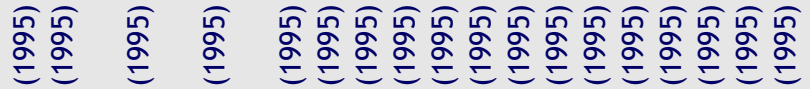

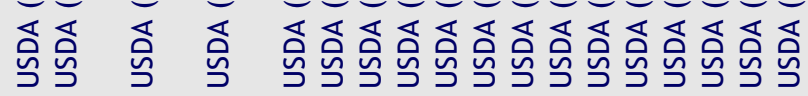




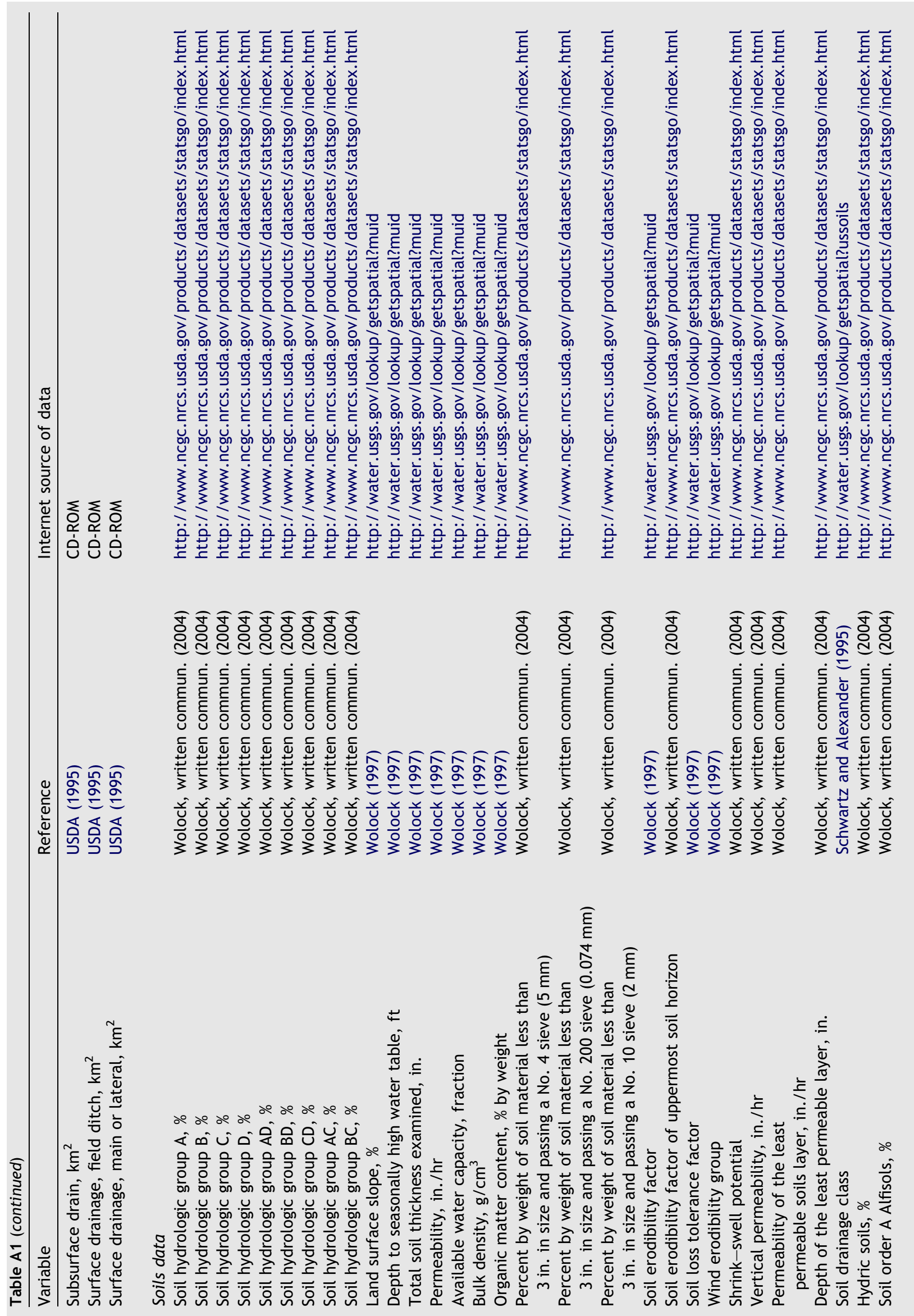




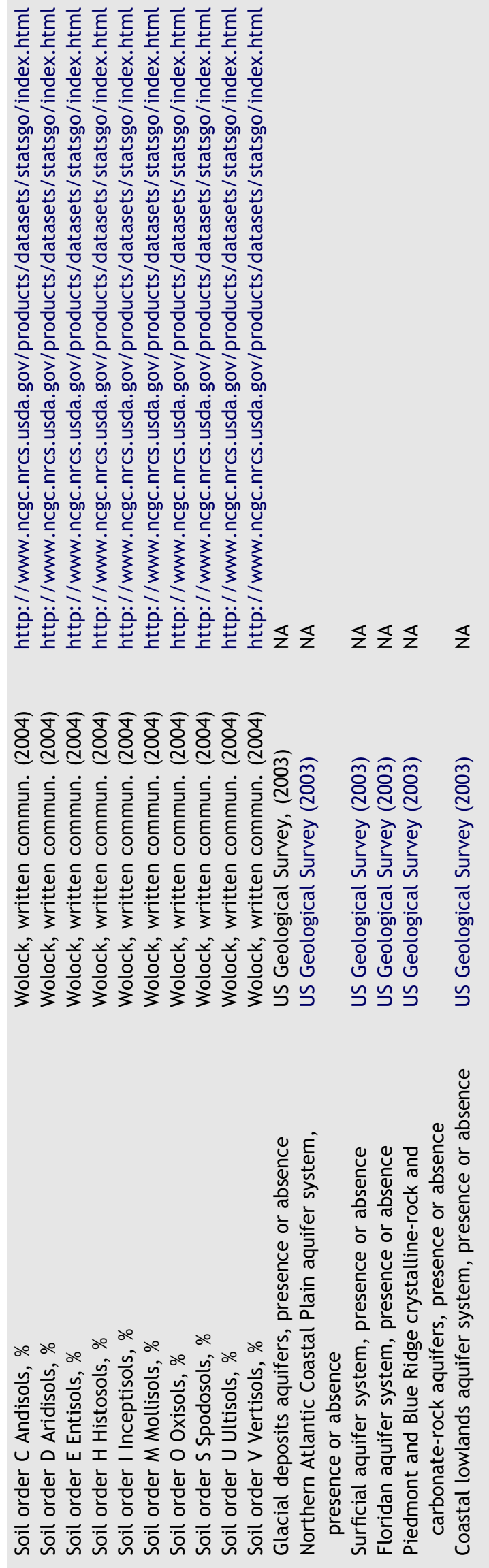

num, and have positive coefficient sign in the model (Table $3)$. They are found in moist areas with considerable precipitation and likely represent leaching conditions indicative of recharge. Sampled areas with high percentages of hydric soils are in TRIN and GAFL, and those with high percentages of Ultisols are primarily in the southeast (PODL and GAFL).

Other factors, such as measured sand (positive sign, $\mathrm{RS}=0.28)$ above the water table and soil hydrologic group A (positive sign, $R S=0.08$ ), indicate primarily a textural effect. These results corroborate an earlier model that predicts that higher recharge when soils in the upper $30 \mathrm{~cm}$ of the profile are coarse-textured (Doll et al., 2002). Greater recharge is expected in areas with coarse-textured soils, which promote rapid infiltration of water.

Land-use factors may represent effects of humans or natural conditions on recharge. Residential land use (negative slope coefficient, RS $=0.10$ ) comprises NLCDe 92 categories 25 (NLCD nonforested/LULC residential) and 26 (NLCD forested/LULC residential), and might indicate areas with relatively impervious surfaces from housing, roads, and other suburban development. High percentages of this combined residential land use are present sporadically throughout the region, particularly in TRIN and CONN. Wetlands (negative slope coefficient, $\mathrm{RS}=0.05$ ) is the least important variable in the model but is retained because it is reasonable from a conceptual standpoint. It likely indicates groundwater exfiltration areas, where the water table intersects the land surface.

\section{Conclusions}

Estimates of ground-water recharge were obtained for selected locations in the eastern US by Darcian and chloridetracer methods. Recharge estimates by chloride tracer are significantly correlated with factors representing climate, hydrology, land use, and soil properties. We emphasized the ground-water chloride tracer $\left(R_{\mathrm{szc}}\right)$ estimates in this research because they had intermediate variability and performed best in the nonlinear regression model. Although the $R_{\mathrm{SzC}}$ methods produced the best results in this study, that may not always be the case. Use of multiple methods is beneficial, because each method has advantages and disadvantages. Explanatory variables that commonly vary over large distances (e.g., mean annual temperature and precipitation) likely led to the improved regression results for the $R_{\mathrm{sZc}}$ method, which provides recharge estimates that are integrated over much larger areas than the $R_{\mathrm{UZC}}$ and $R_{\mathrm{PTF}}$ methods.

We evaluated $R_{\mathrm{SzC}}$ using analysis of variance, multiple comparison tests, and an exploratory nonlinear regression (NLR) model. For the most part, recharge was significantly higher in areas with well-drained soils or those comprising coastal plain surficial aquifers, fractured crystalline rocks, and carbonate rocks. Westernmost portions of the study area have high silt content and comparatively low recharge.

The NLR model comprises precipitation and transport factors and identifies those, in a multi-variate context, that most influence recharge in the region. Sensitivity analysis indicated that, of the more than 100 variables screened in the model, mean annual runoff, air temperature, precipitation, and topographic wetness index had the most influence 
Table A2 Recharge estimates $(\mathrm{cm} / \mathrm{yr})$ by the Darcian-pedotransfer, unsaturated-zone chloride tracer, and saturated-zone chloride tracer methods

\begin{tabular}{|c|c|c|c|c|c|}
\hline $\begin{array}{l}\text { NAWQA } \\
\text { study unit }\end{array}$ & Station identifier & $\begin{array}{l}\text { Sample } \\
\text { identifier }\end{array}$ & $\begin{array}{l}\text { Darcian-pedotransfer } \\
\text { method }\left(R_{\mathrm{PTF}}\right)\end{array}$ & $\begin{array}{l}\text { Chloride tracer in } \\
\text { unsaturated zone }\left(R_{\mathrm{UZC}}\right)\end{array}$ & $\begin{array}{l}\text { Chloride tracer in } \\
\text { saturated zone }\left(R_{\mathrm{SzC}}\right)\end{array}$ \\
\hline CNBR & 411733096185501 & DG-23 & - & - & 1.5 \\
\hline CNBR & 413302097090530 & $\mathrm{~K}-7$ & 47.2 & 3.6 & 10.2 \\
\hline CNBR & 413348096324801 & FP3 & 0.0 & 11.0 & 4.8 \\
\hline CNBR & 413853096483801 & $D-22$ & 1.9 & 0.4 & 0.7 \\
\hline CNBR & 413919096531401 & DO-12 & 3.8 & 4.9 & - \\
\hline CNBR & 414141096371701 & $D-26$ & 0.0 & 4.0 & 4.8 \\
\hline CNBR & 414343096595801 & $\mathrm{CO}-13$ & 57.2 & 2.0 & 5.8 \\
\hline CNBR & 414401096531301 & $D-21$ & 2.0 & 1.5 & 2.1 \\
\hline CNBR & 414527097094101 & $\mathrm{~S}-11$ & 393.2 & 11.3 & 14.8 \\
\hline CNBR & 414948097212601 & S-01 & 0.0 & 0.3 & 0.6 \\
\hline CNBR & 415458097142201 & S-R2 & 512.2 & 8.5 & 15.8 \\
\hline CNBR & 415558096434501 & CU-20 & 32.1 & 3.2 & 11.8 \\
\hline CNBR & 415918096350501 & CU-29 & 0.4 & 6.4 & 23.9 \\
\hline CNBR & 420024096485901 & CU-19 & 0.4 & 7.7 & 9.1 \\
\hline CNBR & 420248096300901 & CU-30 & 21.8 & 4.6 & 7.8 \\
\hline CNBR & 420425097101301 & $S-10$ & 0.0 & 2.4 & 6.9 \\
\hline CNBR & 420526096543901 & $W-14$ & 17.7 & 1.4 & 2.8 \\
\hline CNBR & 421149097121301 & W-09 & 4.2 & 2.4 & 5.6 \\
\hline CNBR & 421303097011601 & W-15 & 1.5 & 3.3 & 5.9 \\
\hline CNBR & 421357097243201 & P-02 & 0.0 & 3.1 & 1.4 \\
\hline CNBR & 421445097123801 & W-RI & 0.1 & 1.4 & 5.0 \\
\hline CNBR & 421829097112401 & W-08 & 1.6 & 2.2 & 32.5 \\
\hline CNBR & 422156097314301 & P-03 & 13.9 & 1.3 & 1.7 \\
\hline CNBR & 422441097404601 & P-04 & 1.1 & 2.0 & 4.6 \\
\hline CNBR & 422756097334901 & K-05 & 1.3 & 1.9 & 1.6 \\
\hline CNBR & 422802097031601 & CE-17 & - & 0.7 & 0.9 \\
\hline CNBR & 422947097142701 & CE-06 & 0.0 & 2.6 & 12.9 \\
\hline CONN & 413122073122401 & CONNCL2 & - & 5.7 & 5.6 \\
\hline CONN & 413126073121101 & CONNCL4 & 13.5 & 22.4 & 18.0 \\
\hline CONN & 413127073122401 & CONNCL3 & - & 8.0 & 7.3 \\
\hline CONN & 413128073120000 & CONNCL5 & 0.0 & 0.7 & 10.2 \\
\hline CONN & 413129073122001 & CONNCL1 & 0.0 & 82.4 & 4.3 \\
\hline CONN & 413130073115801 & CONNBR1 & 537.7 & 17.1 & 15.6 \\
\hline CONN & 413130073120401 & CONNSW2 & - & 24.2 & 21.3 \\
\hline CONN & 413137073120000 & CONNSW4 & 1026.5 & 12.0 & 9.2 \\
\hline CONN & 413138073121201 & CONNSW1 & - & 6.4 & 5.3 \\
\hline CONN & 413144073115701 & CONNSW3 & - & 16.3 & 4.2 \\
\hline CONN & 413925072544401 & CONNRB & - & 1.6 & 19.5 \\
\hline CONN & 414332072555401 & CONNSB & - & 33.9 & 18.3 \\
\hline CONN & 414815072335701 & CONNWM & - & 8.3 & 2.8 \\
\hline CONN & 414826072290901 & CONNMP & - & 10.4 & 154.5 \\
\hline CONN & 414917072403501 & CONNWC & - & 6.1 & 61.8 \\
\hline CONN & 415035072293801 & CONNVR & - & 6.1 & 32.1 \\
\hline CONN & 415101072314901 & CONNMRS & - & 4.1 & 2.7 \\
\hline CONN & 415107072333101 & CONNOC & 4.1 & 5.2 & - \\
\hline CONN & 415148072325601 & CONNNS & - & 3.7 & 4.5 \\
\hline CONN & 415336072414801 & CONNBW & - & 57.7 & 12.4 \\
\hline CONN & 415446072364501 & CONNEI & - & 11.0 & 7.0 \\
\hline CONN & 415453072482901 & CONNMS & - & 39.1 & 10.5 \\
\hline CONN & 415535072475701 & CONNKG & - & 5.8 & 5.8 \\
\hline CONN & 420027072262001 & CONNBS & - & 5.9 & 0.8 \\
\hline CONN & 420339072411701 & CONNPD & - & 1.6 & 33.7 \\
\hline CONN & 420400072370201 & CONNFH & 158.8 & 5.5 & 4.4 \\
\hline CONN & 420550072434601 & CONNWM & 0.7 & 6.1 & 9.2 \\
\hline CONN & 420757072390101 & CONNNW & - & 9.3 & 22.9 \\
\hline
\end{tabular}


Table A2 (continued)

\begin{tabular}{|c|c|c|c|c|c|}
\hline $\begin{array}{l}\text { NAWQA } \\
\text { study unit }\end{array}$ & Station identifier & $\begin{array}{l}\text { Sample } \\
\text { identifier }\end{array}$ & $\begin{array}{l}\text { Darcian-pedotransfer } \\
\text { method }\left(R_{\mathrm{PTF}}\right)\end{array}$ & $\begin{array}{l}\text { Chloride tracer in } \\
\text { unsaturated zone }\left(R_{\mathrm{UZC}}\right)\end{array}$ & $\begin{array}{l}\text { Chloride tracer in } \\
\text { saturated zone }\left(R_{\mathrm{SZC}}\right)\end{array}$ \\
\hline CONN & 421031072311601 & CONNSV & 0.0 & 2.2 & 3.0 \\
\hline CONN & 421118072410401 & CONNHG & 20.2 & 18.9 & 12.0 \\
\hline CONN & 421137072385801 & CONNHC & - & 1.3 & - \\
\hline CONN & 421216072411501 & CONNBL & 0.0 & 0.7 & - \\
\hline GAFL & 280241082224403 & FL-4403 & 11.5 & 4.4 & 8.4 \\
\hline GAFL & 280247082231901 & FL-31901 & 23.7 & 14.6 & 19.6 \\
\hline GAFL & 280249082220703 & FL-20703 & - & 124.1 & 9.2 \\
\hline GAFL & 280253082223803 & FL-803 & 57.1 & 84.1 & 34.3 \\
\hline GAFL & 280301082222702 & FL-2702 & 21.1 & 43.7 & 19.4 \\
\hline GAFL & 280846082134402 & HILLS & - & 9.4 & - \\
\hline PODL & 383653077203701 & PODL87 & 0.2 & 4.1 & 49.8 \\
\hline PODL & 384956077250301 & PODL3849 & 12.9 & 0.6 & 30.6 \\
\hline PODL & 385305077162101 & PODL46 & 0.6 & 3.7 & 14.2 \\
\hline PODL & 385311077215001 & PODL47 & 23.9 & 2.1 & 20.0 \\
\hline PODL & 385930077215901 & PODL35 & 361.2 & 1.1 & 2.4 \\
\hline PODL & 390533077125201 & PODL28 & 390.0 & 1.9 & 2.1 \\
\hline PODL & 390812077051001 & PODL15 & 57.8 & 2.3 & 0.8 \\
\hline PODL & 390906077145601 & PODL16 & 19.4 & - & - \\
\hline PODL & 391102077101901 & PODL05 & 1.0 & 16.1 & 88.2 \\
\hline PODL & 391657076003601 & TRI-1 & - & - & - \\
\hline PODL & 391659076001800 & FS1-1 & - & 23.2 & 33.7 \\
\hline PODL & 391659076001801 & PODLFS1-1 & 107.6 & - & - \\
\hline PODL & 391700076002501 & FS1-2 & 3.1 & - & 34.6 \\
\hline PODL & 391701076003201 & FS1-3 & 93.3 & 5.6 & 172.7 \\
\hline PODL & 391710075584001 & AS1 & - & - & 82.4 \\
\hline TRIN & 294405095412301 & Ref 1 & - & 0.3 & 1.5 \\
\hline TRIN & 294503095373201 & MW29 & - & - & 3.5 \\
\hline TRIN & 294620095440501 & MW17 & - & - & 1.0 \\
\hline TRIN & 294657095412701 & MW30 & 60.7 & - & - \\
\hline TRIN & 294800095415801 & MW28A & 1.3 & - & 0.7 \\
\hline TRIN & 294801095425701 & MW28 & - & 0.5 & - \\
\hline TRIN & 294807095452701 & MW27 & - & 1.5 & 1.1 \\
\hline TRIN & 294919095320501 & MW25 & - & 6.5 & 4.7 \\
\hline TRIN & 294957095310801 & MW26 & 1.8 & 1.5 & 5.0 \\
\hline TRIN & 295049095253101 & MW23 & 3.3 & 0.1 & 2.4 \\
\hline TRIN & 295150095302401 & MW20 & - & 3.1 & 3.7 \\
\hline TRIN & 295232095294101 & MW21 & - & 36.5 & 8.1 \\
\hline TRIN & 295249095411301 & MW16 & 3.5 & - & 2.6 \\
\hline TRIN & 295358095374101 & MW18 & 2.5 & 0.4 & 1.7 \\
\hline TRIN & 295421095305801 & MW19 & 0.9 & 4.8 & 4.7 \\
\hline TRIN & 295557095360901 & MW11 & 1.9 & 0.2 & 1.6 \\
\hline TRIN & 295633095335201 & MW12 & - & 0.3 & 0.8 \\
\hline TRIN & 295711095222301 & MW07 & 18.3 & 8.7 & 5.0 \\
\hline TRIN & 295714095361701 & MW09 & 3.0 & 0.1 & - \\
\hline TRIN & 295720095290001 & MW08 & - & 3.0 & 4.1 \\
\hline TRIN & 300011095251801 & MW10 & - & 0.8 & 10.5 \\
\hline TRIN & 300026095225401 & MW06 & - & 2.7 & 2.5 \\
\hline TRIN & 300044095312001 & MW01 & - & 0.1 & 1.0 \\
\hline TRIN & 300155095200201 & MW05 & 0.0 & 0.1 & 1.5 \\
\hline TRIN & 300351095232601 & MW02 & - & 0.5 & 0.6 \\
\hline TRIN & 300825095274801 & MW14 & 12.2 & 0.6 & 0.1 \\
\hline TRIN & 301008095302901 & MW13 & - & 142.8 & 0.6 \\
\hline TRIN & 301220095305501 & MW15 & 7.3 & 1.3 & 1.1 \\
\hline TRIN & 301716095400501 & Ref03 & 0.1 & 4.7 & 5.4 \\
\hline WHMI & 393230085375302 & TP-2 & 1.9 & 11.7 & 26.0 \\
\hline WHMI & 395025085493501 & Uuk & - & 34.7 & $\begin{array}{l}\quad 6.2 \\
\text { (continued on next page) }\end{array}$ \\
\hline
\end{tabular}




\begin{tabular}{|c|c|c|c|c|c|}
\hline $\begin{array}{l}\text { NAWQA } \\
\text { study unit }\end{array}$ & Station identifier & $\begin{array}{l}\text { Sample } \\
\text { identifier }\end{array}$ & $\begin{array}{l}\text { Darcian-pedotransfer } \\
\text { method }\left(R_{\mathrm{PTF}}\right)\end{array}$ & $\begin{array}{l}\text { Chloride tracer in } \\
\text { unsaturated zone }\left(R_{\mathrm{UzC}}\right)\end{array}$ & $\begin{array}{l}\text { Chloride tracer in } \\
\text { saturated zone }\left(R_{\mathrm{SZC}}\right)\end{array}$ \\
\hline WHMI & 395045085510933 & sVz & 1143.6 & - & - \\
\hline WHMI & 395151085504501 & $2 D$ & 15.2 & 20.0 & 40.7 \\
\hline WHMI & 395159086171501 & WHMI & 12.1 & 0.4 & 0.3 \\
\hline WHMI & 400717085032801 & TP-10 & 7.7 & 13.6 & 9.8 \\
\hline WHMI & 400836085205901 & TP-9 & 12.9 & 13.6 & 40.6 \\
\hline WMIC & 443317089211701 & wmicfss4 & 0.7 & 3.5 & 290.0 \\
\hline WMIC & 443320089212301 & wmicfss 3 & 51.9 & 15.5 & 43.0 \\
\hline WMIC & 443328089213601 & wmicfss2 & 47.5 & 6.2 & 40.6 \\
\hline WMIC & 443338089221501 & wmicfss1 & 12.6 & 37.0 & 45.0 \\
\hline
\end{tabular}

Study unit definitions are: CNBR, Central Nebraska Basins; CONN, Connecticut, Housatonic, and Thames River Basins; GAFL, GeorgiaFlorida Coastal Plain; PODL, Potomac-Delmarva River Basins; TRIN, Trinity River Basin; WMIC, Western Lake Michigan Drainages; WHMI, White-Miami River Basins.

on predictions. Some of the variables, such as runoff and subsurface contact time, are difficult to interpret and may explain residual variation not accounted for by other variables in the model; however, their inclusion results in significant model improvement. Soil characteristics such as measured percent sand have less influence on predicted recharge but nonetheless are highly significant in the model ( $p$ generally $<0.01$ ). Additionally, measured bulk physical properties (texture, moisture content, and bulk density) were key to estimating recharge by the Darcian-pedotransfer method.

Although the NLR model fits the existing data set reasonably well, we consider it exploratory and refrained from using it to predict recharge throughout the region. Sampling was sparse overall, with only 108 estimates of $R_{\text {SzC }}$ available for the eastern US. Future work could involve hundreds or even thousands of $R_{\mathrm{SzC}}$ estimates using ground water and atmospheric chemistry data that are readily available in national databases. An enhanced data set may improve model fit, reduce variability, and enable prediction in unsampled areas.

\section{Appendix 1}

See Tables A1 and A2.

\section{References}

Baehr, A.L., Kauffman, L.J., Perkins, K., Nolan, B.T., 2003. Estimating spatial variability of recharge in southern New Jersey from unsaturated-zone measurements. US Geological Survey Water-Resources Investigations Report 02-4288.

Bayless, E.R., 2001. Atrazine retention and degradation in the vadose zone at a till plain site in central Indiana. Ground Water 39 (2), 169-180.

Beven, K.J., Kirkby, M.J., 1979. A physically based, variable contributing area model of basin hydrology. Hydrological Sciences Bulletin 24, 43-69.

Chong, S.K., Green, R.E., Ahuja, L.R., 1981. Simple in situ determination of hydraulic conductivity by power function descriptions of drainage. Water Resources Research 18, 1109-1114.

Daly, C., Gibson, W.P., Taylor, G.H., Johnson, G.L., Pasteris, P., 2002. A knowledge-based approach to the statistical mapping of climate. Climate Research 22, 99-113.
Delin, G.N., Healy, R.W., Landon, M.K., Bohlke, J.K., 2000. Effects of topography and soil properties on recharge at two sites in an agricultural field. Journal of American Water Resources Association $36(6), 1401-1416$.

Doll, P., Lehner, B., Kaspar, F., 2002. Global modeling of groundwater recharge. In: Schmitz, G.H. (Ed.), Third International Conference on Water Resources and the Environment Research, Dresden, Germany, pp. 27-31.

Fishman, M.J., 1993. Methods of analysis by the US Geological Survey National Water Quality Laboratory: determination of inorganic and organic constituents in water and fluvial sediments. US Geological Survey Open-File Report 93-125.

Fredrick, B.S., Linard, J.I., Carpenter, J.L., 2006. Environmental Setting of Maple Creek Watershed, Nebraska. US Geological Survey. Scientific Investigations Report 2006-5037.

Gardner, W.R., 1964. Water movement below the root zone. In: 8th International Congress of Soil Science, Bucharest, Romania, pp. 317-320.

Gebert, W.A., Graczyk, D.J., Krug, W.R., 1987. Average annual runoff in the United States, 1951-80. US Geological Survey Hydrologic Investigations Atlas HA-710.

Gee, G.W., Or, D., 2002. Particle-size analysis. In: Dane, J.H., Topp, G.C. (Eds.), Methods of Soil Analysis, Part 4-Physical Methods: Soil Science Society of America Book Series No. 5. Soil Science Society of America, Madison, WI, pp. 255-293.

Görres, J., Gold, A.J., 1996. Incorporating spatial variability into GIS to estimate nitrate leaching at the aquifer scale. Journal of Environmental Quality 25, 491-498.

Grossman, R.B., Reinsch, T.G., 2002. Bulk density and linear extensibility. In: Dane, J.H., Topp, G.C. (Eds.), Methods of Soil Analysis, Part 4-Physical Methods. Soil Science Society of America, Madison, WI, pp. 201-228.

Hamon, W.R., 1961. Estimating potential evapotranspiration. Journal of Hydraulics Division-ASCE 87, 107-120.

Helsel, D.R., Hirsch, R.M., 1992. Statistical Methods in Water Resources. Studies in Environmental Science, vol. 49. Elsevier, New York, 522 pp.

Koterba, M.T., Wilde, F.D., Lapham, W.W., 1995. Ground-water data-collection protocols and procedures for the National Water-Quality Assessment Program: collection and documentation of water-quality samples and related data. US Geological Survey Open-File Report 95-399, Reston, VA.

Land, L.F., Moring, J.B., Metre, P.C.V., Reutter, D.C., Mahler, B.J., Shipp, A.A., Ulery, R.L., 1998. Water quality in the Trinity River Basin, TX, 1992-95. US Geological Survey Circular 1171.

McMahon, P.B., Dennehy, K.F., Michel, R.L., Sophocleous, M.A., Ellett, K.M., Hurlbut, D.B., 2003. Water movement through thick unsaturated zones overlying the central High Plains Aquifer, 
Southwestern Kansas, 2000-2001. US Geological Survey WaterResources Investigations Report 03-4171.

Nakagaki, N., Wolock, D.M., 2005. Estimation of agricultural pesticide use in drainage basins using land cover maps and county pesticide data. US Geological Survey Open-File Report 2005-1188.

National Atmospheric Deposition Program (NRSP-3), 2006. NADP/ NTN National Trends Network. NADP Program Office, Champaign, IL. Data accessed in March 2006. Available from: <http:// nadp.sws.uiuc.edu/>.

Nichols, D.S., Verry, E.S., 2001. Stream flow and ground water recharge from small forested watersheds in north central Minnesota. Journal of Hydrology 245 (1), 89-103.

Nimmo, J.R., Deason, J.A., Izbicki, J.A., Martin, P., 2002. Evaluation of unsaturated zone water fluxes in heterogeneous alluvium at a Mojave Basin site. Water Resources Research 38 (10), 1-13.

Nimmo, J.R., Stonestrom, D., Healy, R.W., 2003. Aquifer Recharge. Encyclopedia of Water Science. Marcel Dekker Inc., pp. 1-4.

Nolan, B.T., Baehr, A.L., Kauffman, L.J., 2003. Spatial variability of ground-water recharge and its effect on shallow ground-water quality in southern New Jersey. Vadose Zone Journal 2, 677-691.

Petach, M.C., Wagenet, R.J., DeGloria, S.D., 1991. Regional water flow and pesticide leaching using simulations with spatially distributed data. Geoderma 48, 245-269.

Rangarajan, R., Athavale, R.N., 2000. Annual replenishable ground water potential of India - an estimate based on injected tritium studies. Journal of Hydrology 234 (1), 38-53.

Ruddy, B.C., Lorenz, D.L., Mueller, D.K., 2006. County-level estimates of nutrient inputs to the land surface of the conterminous United States, 1982-2001. US Geological Survey Scientific Investigations Report 2006-5012.

Scanlon, B.R., Healy, R.W., Cook, P.G., 2002. Choosing appropriate techniques for quantifying groundwater recharge. Hydrogeology Journal 10, 18-39.

Schaap, M.G., Leij, F.J., van Genuchten, M.T., 1998. Neural network analysis for hierarchical prediction of soil hydraulic properties. Soil Science Society of America Journal 62 (4), 847-855.

Schaap, M.G., Leij, F.J., van Genuchten, M.T., 2001. Rosetta: a computer program for estimating soil hydraulic parameters with hierarchical pedotransfer functions. Journal of Hydrology 251, 163-176.

Schwartz, G.E., Alexander, R.B., 1995. State Soil Geographic (STATSGO) database for the Conterminous United States. U.S. Geological Survey Open-File Report 95-449. Available from <http:// water.usgs.gov/lookup/getspatial?ussoils>.

Sisson, J.B., 1987. Drainage from layered field soils: fixed gradient models. Water Resources Research 23, 2071-2075.

Smith, R.A., Schwartz, G.E., Alexander, R.B., 1997. Regional interpretation of water-quality monitoring data. Water Resources Research 33 (12), 2781-2798.

Solley, W.B., Pierce, R.R., Perlman, H.A., 1998. Estimated use of water in the United States in 1995. US Geological Survey Circular 1200.

Sophocleous, M.A., 1992. Groundwater recharge estimation and regionalization: The Great Bend Prairie of central Kansas and its recharge statistics. Journal of Hydrology 137, 113-140.

Soutter, M., Pannatier, Y., 1996. Groundwater vulnerability to pesticide contamination on a regional scale. Journal of Environmental Quality 25, 439-444.

Thornton, P.E., Running, S.W., 1999. An improved algorithm for estimating incident daily solar radiation from measurements of temperature, humidity, and precipitation. Agriculture and Forest Meteorology 93, 211-228.

Topp, G.C., Ferre, P.A., 2002. Water content - physical methods. In: Dane, J.H., Topp, G.C. (Eds.), Methods of Soil Analysis - Part 4. Soil Science Society of America, Madison, WI, pp. 417-420.

US Bureau of the Census, 1991. 1990 Census of Population and Housing, Public Law 94-171 Data (United States). Data accessed in March 2006. Available from: <http://water.usgs.gov/lookup/ getspatial?uspop90>.

US Bureau of the Census, 1992. Census of population and housing, 1990-Summary tape file 3A on CD-ROM (machinereadable data file). The Bureau (producer and distributor), Washington, DC.

US Department of Agriculture, 1994. State Soil Geographic (STATSGO) data base for the United States and Puerto Rico (CDROM). Natural Resources Conservation Service, Ft. Worth, TX.

US Department of Agriculture, 1995. 1992 National Resources Inventory (CDROM). Natural Resources Conservation Service, Washington, DC, and Statistical Laboratory, lowa State University, Ames, lowa.

US Department of Agriculture, 2001. National Soil Survey Handbook, title 430-VI. Natural Resources Conservation Service, Washington, DC. Online source accessed in March 2006. Available from: <http://soils.usda.gov/technical/handbook/>.

US Department of Agriculture, 2006. US Fertilizer Use and Price-US Consumption of Selected Phosphate and Potash Fertilizers. Economic Research Service, Washington, DC. Data accessed in March 2006. Available from: <http://www.ers.usda.gov/Data/ FertilizerUse/>.

US Environmental Protection Agency, 2006. Clean Air Status and Trends Network (CASTNET). National Dry Deposition Network (NDDN), Washington, DC. Data accessed in March 2006. Available from: <http://www.epa.gov/castnet/>.

US Geological Survey, 1987. Digital elevation models-data users guide 5. US Geological Survey, Reston, VA, 48 pp.

US Geological Survey, 1990. Land use and land cover digital data from 1:250,000- and 1:100,000-scale maps-data users guide 4 . US Geological Survey, Reston, VA, 25 pp.

US Geological Survey, 2003. Principal aquifers of the 48 conterminous United States, Hawaii, Puerto Rico, and the U.S. Virgin Islands, in National Atlas of the United States of America. US Geological Survey, Reston, VA. Data accessed in March 2006. Available from: <http://www. nationalatlas.gov>.

van Genuchten, M.T., 1980. A closed form equation for predicting the hydraulic conductivity of unsaturated soils. Soil Science Society of America Journal 44, 892-898.

Vitvar, T., Burns, D.A., Lawrence, G.B., McDonnell, J.J., Wolock, D.M., 2002. Estimation of baseflow residence times in watersheds from the runoff-hydrograph recession - Method and application in the Neversink Watershed, Catskill Mountains, New York. Hydrological Processes 16, 1871-1878.

Vogelmann, J.E., Howard, S.M., Yang, L., Larson, C.R., Wylie, B.K., Van Driel, N., 2001. Completion of the 1990s national land cover dataset for the conterminous United States from Landsat Thematic Mapper data and ancillary data sources. Photogrammetric Engineering and Remote Sensing 67, 650-662.

Wolock, D.M., 1993. Simulating the variable-source-area concept of watershed hydrology with TOPMODEL. US Geological Survey Water-Resources Investigations Report 93-4124.

Wolock, D.M., 1997. STATSGO soil characteristics for the conterminous United States. US Geological Survey Open-File Report 656.

Wolock, D.M., 2003a. Base-flow index grid for the conterminous United States. US Geological Survey Open-File Report 03-263.

Wolock, D.M., 2003b. Estimated mean annual natural ground-water recharge in the conterminous United States. US Geological Survey Open-File Report 03-311.

Wolock, D.M., 2003c. Flow characteristics at US Geological Survey streamgages in the conterminous United States. US Geological Survey Open-File Report 03-146.

Wolock, D.M., 2003d. Saturation overland flow estimated by TOPMODEL for the conterminous United States. US Geological Survey Open-File Report 03-264.

Wolock, D.M., McCabe, G.J., 1995. Comparison of single and multiple flow direction algorithms for computing topographic parameters in TOPMODEL. Water Resources Research 31, 1315-1324. 